\title{
A Late Carboniferous olistostrome at the front of the Southern Tian Shan nappes (Kadamzhai and Khaidarkan deposits, Kyrgyzstan)
}

\author{
Oleh HNYLKO ${ }^{1, *}$, Ihor TSUKORNYK², Larysa HENERALOVA ${ }^{2}$ and Oleksiy DVORZHAK ${ }^{2}$ \\ 1 Institute of Geology and Geochemistry of Combustible Minerals of NAS of Ukraine, Naukova 3a, Lviv 79060, Ukraine \\ 2 Ivan Franko National University of Lviv, Faculty of Geology, Mykhaila Hryshevskoho 4, Lviv 79005, Ukraine
}

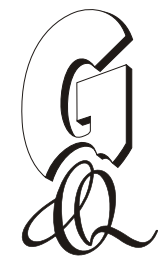

\begin{abstract}
Hnylko, O., Tsukornyk, I., Heneralova, L., Dvorzhak, O., 2019. A Late Carboniferous olistostrome at the front of the Southern Tian Shan nappes (Kadamzhai and Khaidarkan deposits, Kyrgyzstan). Geological Quarterly, 63 (2): 407-423, doi: 10.7306/gq. 1478
\end{abstract}

Associate editor: Anna Wysocka

A Late Carboniferous (Early Moscovian) olistostrome developed in the Kadamzhai and Khaidarkan gold-antimony-mercury deposits on the Alay Ridge northern slope (Kyrgyzstan), at the front of the Late Paleozoic Southern Tian Shan nappes, is characterized. It comprises a sub-nappe olistostrome in a collisional tectonic setting. The olistostrome contains olistoliths and olistoplaques containing parts of the mid-Paleozoic sedimentary successions belonging to the parautochthon and lower nappes of the northern Bukantau-Kokshaal branch of the Southern Tian Shan nappe belt. The olistostrome accumulated ahead the advancing nappes in the foredeep basin that was filled with turbidities and debris-flow deposits (Tolubai Formathion). The parautochthon was partly dismembered into thrust limestone sheets which disintegrated and slid into unconsolidated sediments of the foredeep basin, forming large limestone olistoliths and olistoplaques. Olistoliths containing shales and bedded cherts were slid from the lower nappes. Tectonic breccias up to melange scale are present in some olistoliths, suggesting tectonic disintegration within the nappe pile and the subsequent sliding of the tectonized blocks into the olistostrome basin. Ore-bearing silicified rocks (so-called "jasperoids") with antimony-mercury and gold mineralization are located predominantly along the contacts of the limestone olistoliths/olistoplaques with a terrigenous matrix.

Key words: olistostrome, nappe, Southern Tian Shan, Kadamzhai, Khaidarkan, Kyrgyzstan.

\section{INTRODUCTION}

The term "olistostrome" was first introduced by Flores $(1955,1959)$ to represent subaqueous sedimentary bodies with blocks (olistoliths) chaotically immersed in a finer-grained matrix. It was considered that an olistostrome is a sufficiently large unit to be mapped. Commonly, olistostromes are very thick and extend for tens, in places hundreds, of kilometres (Leonov, 1981). The terms "matrix" and "olistolith" depend on the scale under consideration, for example small blocks are referred to as olistoliths in exposures, and the same blocks can be depicted as part of the matrix on geological maps. The matrix is the product of mud/debris-flows accompanying submarine landslides. Olistoliths are represented by relatively coherent transported blocks of rock. Huge plate-like olistoliths were described by Richter (1973) as olisthoplaques.

Olistostromes reflect mass-wasting processes and gravity-induced emplacement of unsorted sediments and may be

\footnotetext{
* Corresponding author, e-mail: ohnilko@yahoo.com
}

Received: January 22, 2019; accepted: April 19, 2019; first published online: June 13, 2019 associated with turbidites. Most olistostromes were derived from uplifted orogenic fronts as well as from the uplifted parts of rift/passive margin basins (Leonov, 1981; Wendorff, 2005; Lucente and Pini, 2008; Cieszkowski et al., 2009; Golonka et al., 2015; Festa et al., 2016 with references therein).

The criteria for distinction of olistostromes from texturally similar melanges are as follows: Olistostromes are sedimentary in origin, whereas melanges contain blocks embedded in a tectonically sheared matrix, and therefore they are of tectonic genesis. An olistostrome heavily overprinted by tectonic deformation may be indistinguishable from a melange (Hsü, 1974; Leonov, 1981; Festa et al., 2016 with references therein).

Late Carboniferous olistostromes are widely developed in the Late Paleozoic synorogenic flysch of the Southern Tian Shan orogen, and are represented by olistoliths of Carboniferous and more ancient limestones and other rocks within a terrigenous matrix. They are exposed on the Alay Ridge northern slope including the Chauvai, Kadamzhai and Khaidarkan gold-antimony-mercury deposit fields (Kyrgystan). Mikhailov (1947), Cherenkov (1964, 1973), Porshnyakov (1968), Kurenkov (1978), Kukhtikov et al. (1983), Zhdan (1985), Chernyshuk (1986), Belousov and Beer (1989), Belousov (1998), Nenakhov and Belov (2000) and Nenakhov et al. (1992) described the olistostromes in different areas of the Southern Tien Shan. Porshnyakov (1968) was the first to propose a 
model linking thrust to olistostrome in the Paleozoic of the Alay Ridge, while schemes discussed by Cherenkov $(1964,1973)$ and Kukhtikov et al. (1983) were based on a more "fixist" concept inferring formation of the olistostrome without nappe thrusting.

Porshnyakov (1968), Zubtsov and Porshnyakov (1995) and Zubtsov (1997) attributed the thin rafts plates of Devonian-Carboniferous limestone (the so-called "Zuzanov Limestone") developed within the younger Late Carboniferous flysch in the area of Khaidarkan, Kadamzhai and Chauvai deposits to thin tectonic nappes and/or tectonic lenses. These authors noted the possible relation of such limestone units (or their parts) to olistostromes as well as to the source areas as slid limestone blocks gravitationally transported into the surrounding terrigenous sediments. Vishnevsky et al. $(1978,1982)$ attributed the "Zuzanov Limestone" and similar limestone units to the olistostrome formations. Belousov and Beer (1989) and Belousov (1998) expressed the idea that the limestone bodies bearing the antimony-mercury mineralization on the Khaidarkan and Kadamzhay deposit fields belong to large olistoplaques or gravitational nappes.

Olistostromes developed in the Kadamzhai and Khaidarkan deposit fields were schematically depicted on the Geological Map of the USSR (Turkestan-Alay sheets, scale 1: 50,000) prepared for printing (Belov et al., 1991) but unfortunately not published due to the political situation.

Chernyshuk (1986) considered that the formation of some olistostromes on the Kauzan antiform (location see below) area was related to the destruction of thrust slices composed of Middle Paleozoic effusive-siliceous-calcareous and terrigenous-siliceous strata. Nenakhov et al. (1992) attributed the Late Paleozoic olistostromes associated with turbidites to so-called "frontal" processes due to erosion of the uplifted front of the nappes. Biske (1996) suggested that the limestone olistoliths within the Late Carboniferous flysch are most likely derived from tectonic slices of the Alay Nappe (parautochthonous structural unit in this article, see below) of the Southern Tian Shan orogen. Burtman (2006) inferred the existence of two sources for this olistostrome: in Early Moscowian time, the slides were displaced from the south with the uplifted paratochthonous limestone massif, and in the Late Moscovian time, the clasts were emplaced from the north together with the nappe pile filled with pelagic cherts and limestones, and these were added to the southern material.

It should be noted, that the olistostrome formations were not described in detail and not depicted on the detailed geological maps of the area of the Kadamzhai and Khaidarkan deposits. At the same time, the study of these formations is of practical importance, since the ore-bearing silicified rocks (the so-called "jasperoids") are confined to the contacts of limestone bodies (olistoliths in many cases) and terrigenous sediments (Vaulin, 2016; Nevolko et al., 2019). This paper describes the geological position and structure, and interprets the tectonic-sedimentary origin, of the Late Carboniferous olistostrome exposed in the area of the Kadamzhai and Khaidarkan deposits.

\section{GEOLOGICAL SETTING}

The Tian Shan belongs to the Central Asian Orogenic Belt (Fig. 1) formed as a result of the evolution and subsequent closure of the Palaeo-Asian Ocean and collisions of the Siberian, Kazakhstan, Tarim and North China continents (Zonenshain et al., 1990; Dobretsov et al., 1995; Windley et al., 2007; Safonova et al. 2017 with references therein). The Tian Shan extends for over $2500 \mathrm{~km}$ from western Uzbekistan, through Tajikystan, Kyrgyzstan and southern Kazakhstan to western China, and represents the Paleozoic fold-thrust belts which were formed during amalgamation of Eurasia (Burtman, 2006, 2015; Biske and Seltmann, 2010; Biske, 2015, 2018 with references therein). The Kyrgyz Tian Shan Mountains are traditionally subdivided into the Northern Tian Shan, Middle Tian Shan and Southern Tian Shan (Fig. 2).

In Kyrgyzstan, the Northern Tian Shan consists of several Precambrian metamorphic blocks accreted during the Ordovician. The Middle Tian Shan terrane represents a single block of Precambrian continental crust framed from the south by an Ordovician to Lower Silurian accretionary complex (Alexeiev et al., 2016; Biske, 2018). It collided with the continental blocks of the Northern Tian Shan during the Ordovician. As a result, the new Kyrgyz-Kazakh continent was formed (Zubtsov et al., 1974; Windley et al., 2007; Ghes, 2008; Alexeiev et al., 2016).

The Southern Tian Shan is a Late Paleozoic fold-nappe belt which formed as a result of collision of the Kyrgyz-Kazakh continent with the Alay-Tarim and Karakum-Tajik continental blocks (Fig. 2; Biske and Seltmann, 2010; Burtman, 2015; Biske, 2018).

The area studied includes the Kadamzhai and Khaidarkan gold-antimony-mercury deposits, which together with other deposits (Chauvai, Abshyr) belong to the South Fergana antimony-mercury belt, comprising a large ore province (see Vaulin, 2016; Nevolko et al., 2019 and references therein). It is located in the Southern Tian Shan on the northern slope of the Alay Range in the South Fergana mountain region to the south of the Fergana Depression. The area belongs to the Alay segment of the northern (Bukantau-Kokshaal after Biske, 1996, 2015) branch of the Southern Tian Shan fold-nappe belt (Figs. 2 and 3). This segment was formed as a result of the Turkestan Ocean (a Palaeo-Asian Ocean branch then present between the Kyrgyz-Kazakh and Tarim continents) lithosphere subduction beneath the active Kyrghyz-Kazakh continental margin with subsequent (after collision and closure of the Turkestan Ocean in Moscovian age) incorporation of the northern passive margin of the Alay microcontinent (possible western continuation of the Tarim) into the subduction zone, which was inclined to the north. As a result, the south-directed nappe belt was built both of ocean-derived slices and of the detached Paleozoic cover of the Alay microcontinent (Biske, 1996, 2015; Burtman, 2006, 2015; Biske and Seltmann, 2010).

The Alay segment of the Bukantau-Kokshaal nappe pile is bounded to the north by the suture of the Turkestan Ocean (see Burtman, 2006; Biske and Seltmann, 2010; Biske, 2018) and from the south by a foredeep-type basin with Late Paleozoic flysch and molasse deposits (Biske, 1996, 2015; see Fig. 2). 


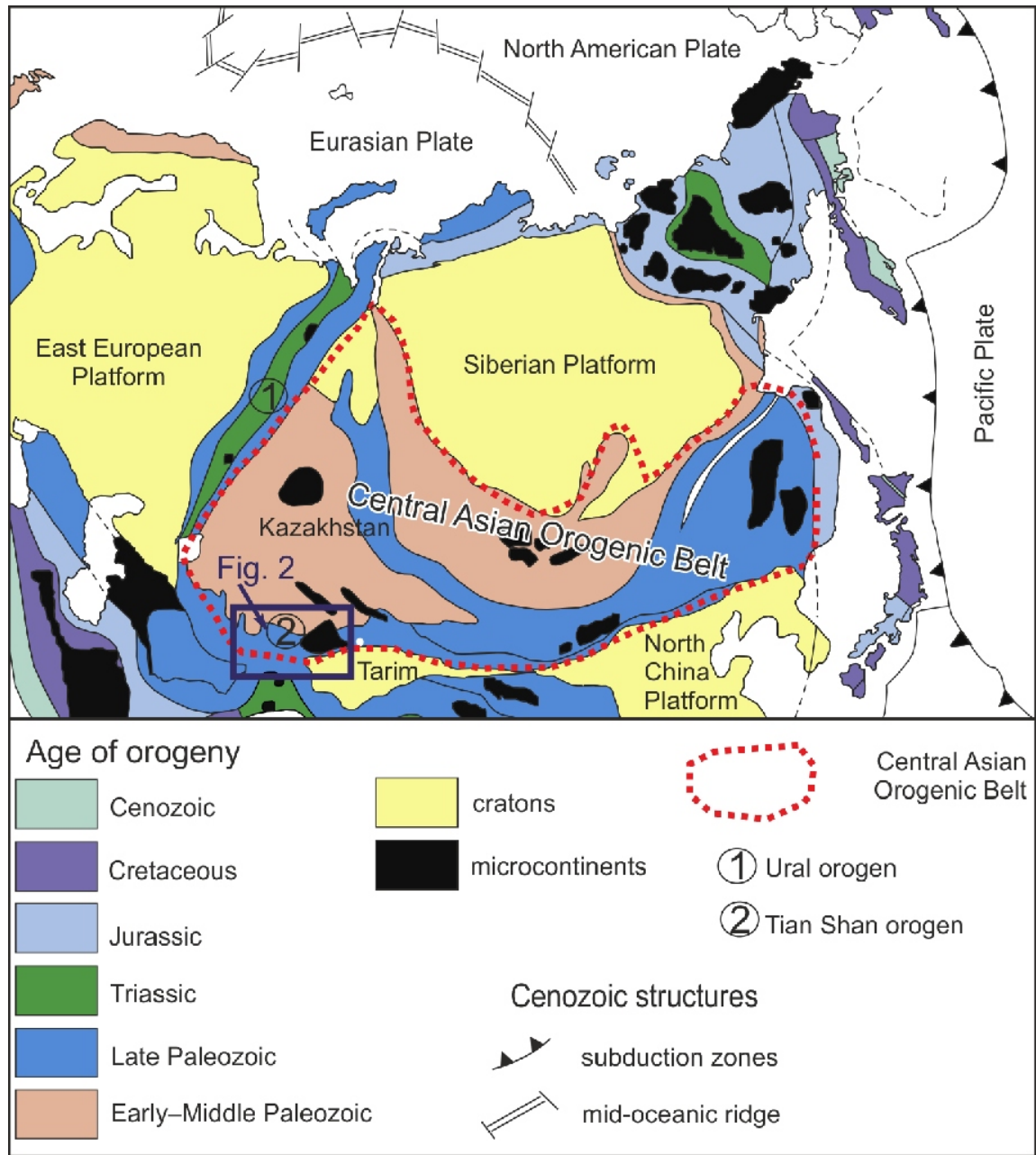

Fig. 1. Tectonic outline of the Central Asia Orogenic Belt and surrounding areas (after Safonova et al., 2017)

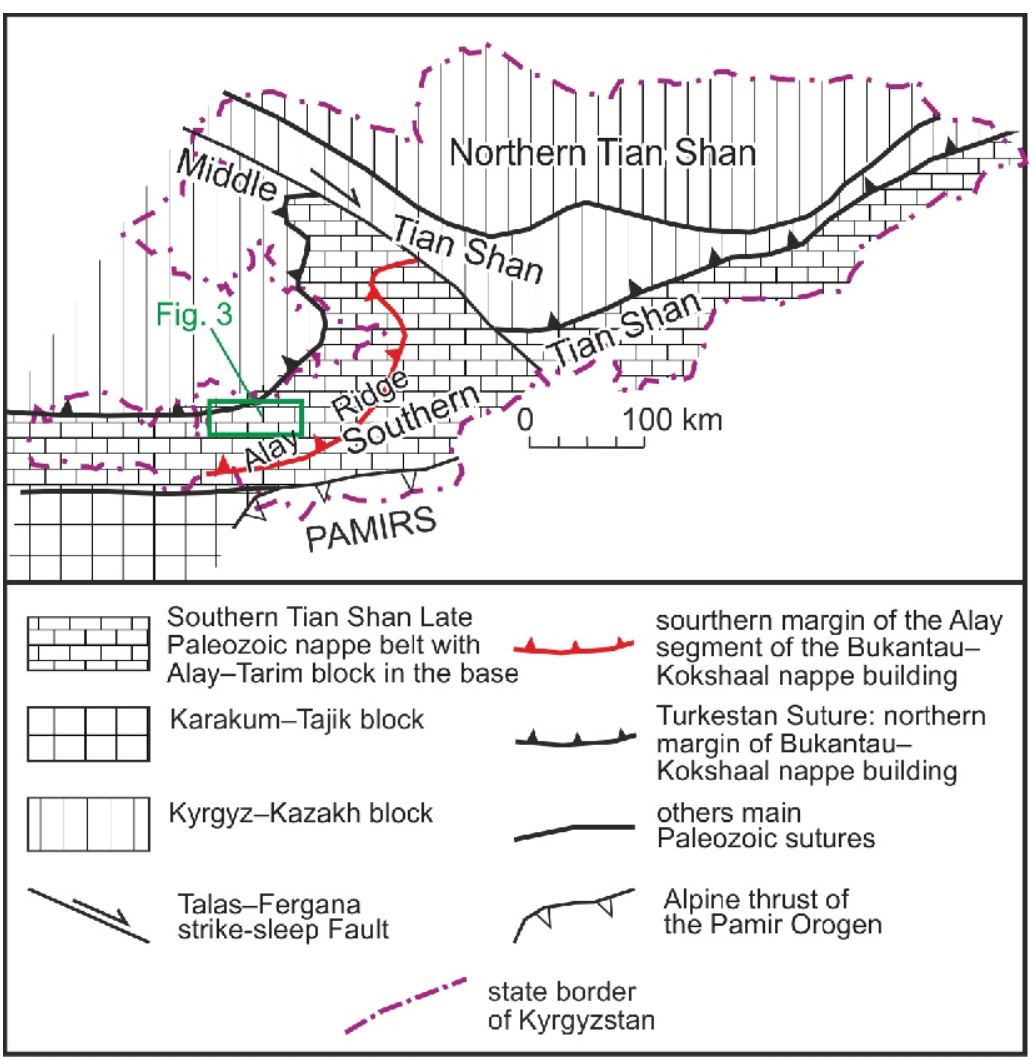

Fig. 2. The main tectonic units of Kyrgyztan (after Biske,1996; Burman, 2006; Biske and Seltmann, 2010; modified) 


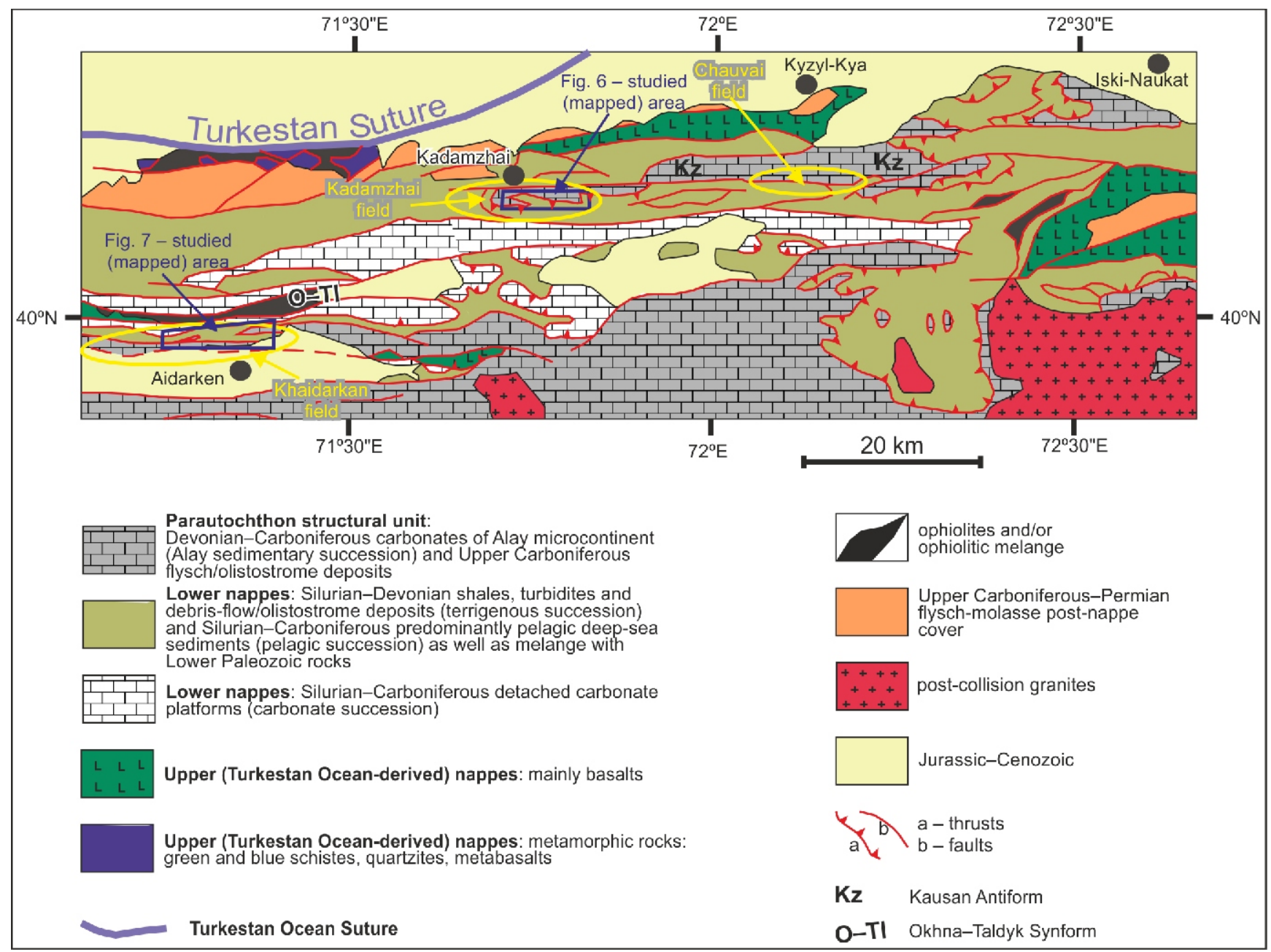

Fig. 3. The tectonic units of the northern (Bukantau-Kokshaal) branch of the Southern Tian Shan fold-nappe belt (the Alay segment including the Chauvai, Kadamzhai and Khaidarkan deposit fields; modified from Biske, 1996; Konopelko et al., 2018: fig. 3)

The Alay segment consists of several structural units (Fig. 3) made up of various Middle Paleozoic sedimentary successions. The parautochthonous unit is made of formations of (1) the Alay sedimentary succession, comprising mainly Devonian-Carboniferous shallow-marine shelf-type limestones of the Alay microcontinent. This sedimentary succession is composed of a number of similar limestone formations (see below) hereinafter simply termed the "Alay limestones". Above it are the lower nappes, made up of rocks of three sedimentary successions: (2) Silurian-Devonian shales, turbidites and debris-flow/olistostrome formations (terrigenous successions); (3) Silurian-Carboniferous predominantly pelagic deep-sea deposits; (4) detached Silurian-Carboniferous carbonate platforms. The upper nappes are of oceanic (Turkestan Ocean) origin (Biske, 1996, 2015; Nenahov and Belov, 2000; Burtman, 2006, 2015).

The term "parautochthon" is used due to this unit being autochthonous relative to the lower nappes and simultaneously being thrusted onto the foredeep-type flysch and younger molasse sediments south of the area studied (Biske, 1996, 2015).

Synorogenic Late Carboniferous turbidites (flysch) was deposited on the top of the sedimentary successions of these nappes and with further nappes being tectonically emplaced above this. The flysch shows some rejuvenation from the upper nappes to the lower ones that suggests younging of thrusting from the upper to the lower structural units. (Biske, 1996, 2015; Burtman, 2006; see Fig. 4).

Such Late Carboniferous synorogenic flysch is developed on top of the parautochthonous sedimentary succession. It lies on the Alay limestones and is tectonically covered by the lower nappe made of Silurian-Devonian turbidites. The synorogenic flysch belongs to the Tolubai Formation (Early Moscovian in age according to foraminiferal data: see Djenchuraeva, 1979) and is represented by gravel-sandy-clay-marl turbidites and also includes olistostrome in the upper part of the Tolubai Formation: coarse submarine debris-flow deposits with large olistoliths/olistoplaques comprising mainly Alay limestones (Vishnevsky et al., 1982; Chernyshuk, 1986; Nenakhov et al., 1992; Biske, 1996 with references therein). This olistostrome exposed in the area of Kadamzhai and Khaidarkan deposits is the object of our research (Figs. 4 and 5).

The package of tectonic nappes of the Southern Tian Shan was deformed into folds (antiforms and synforms) as a result of further collisional compression in the Late Paleozoic. The Kausan Antiform and Okhna-Taldyk Synform are such large folds (Biske, 1996, 2015 with references therein; see Fig. 3). The Kadamzhai deposit is situated on the Kausan Antiform, and the Haydarkan deposit is located on the northern flank of the Okhna-Taldyk Synform. 


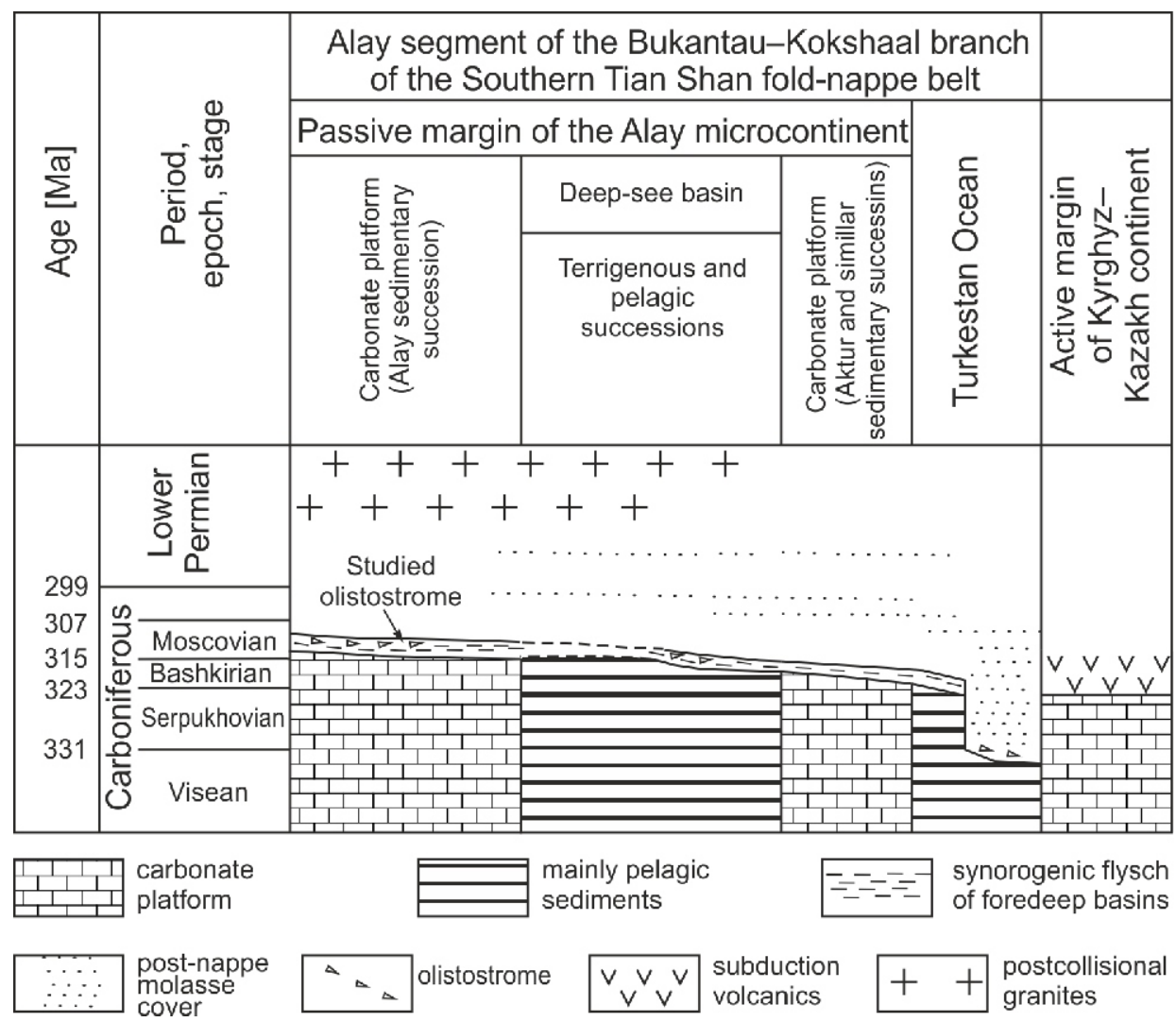

Fig. 4. Correlation of the main formations of the Alay segment of the Bukantau-Kokshaal fold-nappe pile (after Biske, 1996, 2015; modified)

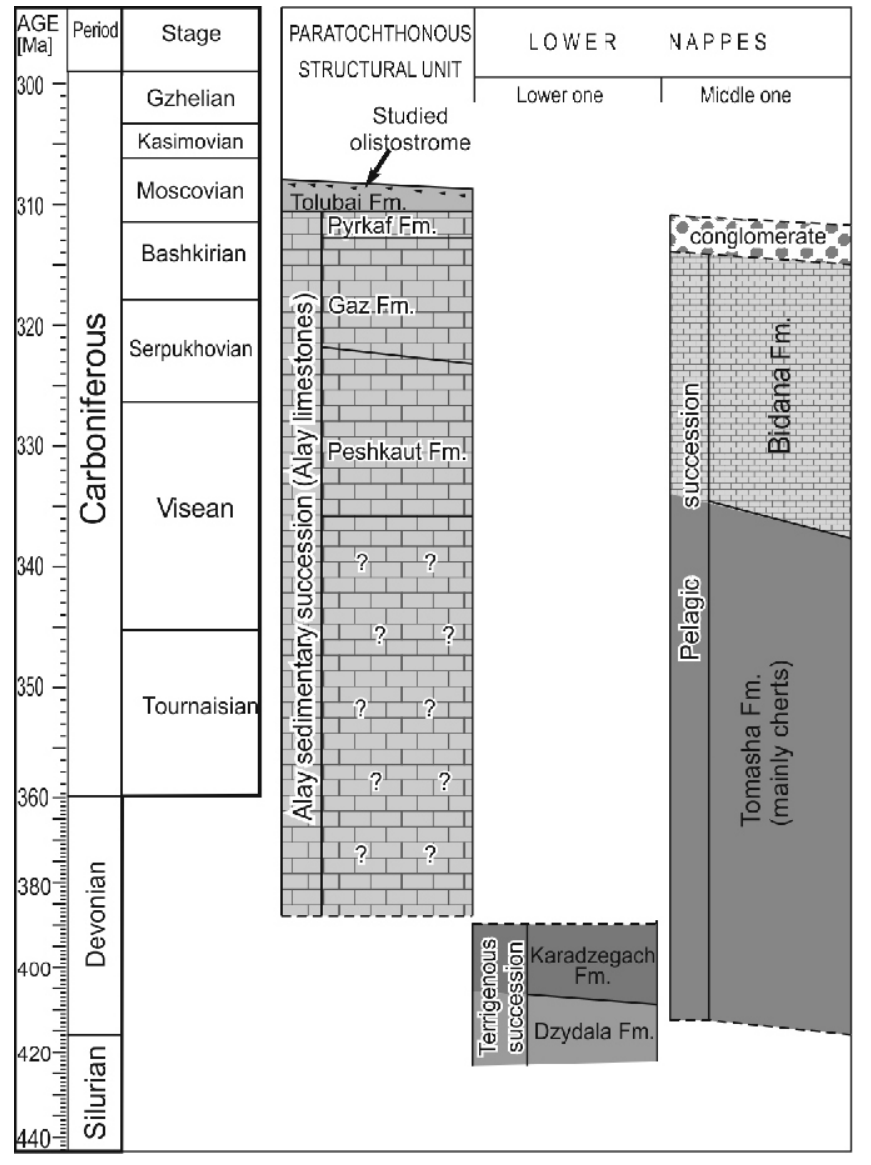

Tectonic melanges with fragments of Paleozoic rocks are developed within the Southern Tian Shan nappe construction (Biske, 1983, 1996, 2015 with references therein). Additionally, the South Tian Shan orogen was broken up by subvertical faults of predominantly strike-slip type. Closer to the axial part of the Alay range, post-collisional granitoid magmatism took place in the Early Permian (see Konopelko et al., 2018 and references therein).

In Mesozoic-Cenozoic times, this territory was developed as a stable platform. In the Alpine stage, a modern high-mountainous relief was formed, as well as a new faults and gentle folds originating due to collision of India and Eurasia.

\section{METHODS}

Geological mapping of the Kadamzhai and Khaidarkan fields (see Fig. 3) at the scale of 1:10,000 with details at 1:5000 and 1:2500 was carried out by the authors during fieldwork in 2017-2018. Geological interpretation of satellite images were used. Fieldwork was supplemented by lithostratigraphical and sedimentological studies as well as via analysis of local tectonics. Detailed field mapping enabled the identification of localities with olistostromes and large olistoliths. Particular attention was

Fig. 5. The lithostratigraphical scheme of the sedimentary formations located in the area studied (mapped)

Lithostratigraphic units and discussion of their age from published literature (Djenchuraeva, 1979; Aristov and Chernyshuk, 1984; Biske, 1996 and references therein, see also Osmonbetov et al., 1982; Sabirov, 2012) 
paid to the study of exposed contacts between the flysch/flyschoidal-type deposits and the large bodies of limestone (olistoliths and/or tectonic fragments).

\section{MAPPED TECTONIC UNITS}

Four tectonic units and their destructured fragments are developed in the areas studied and mapped in the Kadamzhai and Khaidarkan deposit fields (see Fig. 3). The correlation and age of the mapped sedimentary formations comprising these units is shown in Figure 5.

The first (parautochthonous) unit is made of both Carboniferous shallow-marine shelf-type Alay limestones (Cal) and Early Moscovian flysch/olistostrome of the Tolubai Formation $\left(\mathrm{C}_{2} t /\right)$. In the area studied, the Alay limestones are represented by the Peshkaut $\left(\mathrm{C}_{1} p s\right)$, Gaz $\left(\mathrm{C}_{1-2} g z\right)$ and Pyrkaf $\left(\mathrm{C}_{2} p r\right)$ formations conformably lying on top of each other. More ancient Devonian carbonate rocks might also be developed (Fig. 5). The Peshkaut Formation is represented by light grey massive and thick-layered usually micritic limestones. Its lower surface is truncated by faults. The Gaz Formation is composed of dark grey to black micritic limestone with layers and lenses of black chert. The Pyrkaf Formation comprises light grey medium-layered limestone with fusulinid fossils. The Peshkaut, Gaz and Pyrkaf formations are strongly dislocated, which makes it difficult to determine their true thickness, probably their total thickness reaches a hundred metres in the area studied. These formations are not always clearly distinguishable and are shown on the maps as undifferentiated Alay limestones (Cal) (see Figs. 6-9).

The Tolubai Formation overlaps the Pyrkaf Formation and is represented by medium-bedded flysch (carbonate and siliciclastic turbidites) with debris-flow deposits containing clasts of Alay limestone, chert of the pelagic sedimentary succession, shale and sandstone. The thickness of the Tolubai Formation reaches a few hundred metres. An olistrostrome with large olistoliths of the Alay limestones is present in the top of the Tolubai Formation and will be described below.

The second tectonic unit belongs to a lower part of the lower nappes and is made up of a terrigenous sedimentary succession thrusted onto the parautochthonous unit. The terrigenous succession is represented by the Dzydala Formation $\left(\mathrm{S}_{2}-\mathrm{D}_{1} d z\right)$ and Karadzegach Formation $\left(\mathrm{D}_{1} k d\right)$. The Dzydala Formation is composed of green and dark to black clay, slightly metamorphosed shale, fine- and medium-bedded flysch (siliciclastic turbidites). The Karadzegach Formation overlaps the Dzydala Formation and is represented by conglomerates/debris-flow deposits with clasts of limestone, chert, shale and sandstone, as well as containing olistoliths of limestone and yellow dolomite. According to Zubtsov and Porshnyakov (1995), yellow dolomites form separate tectonic units in the structure of the Kauzansky antiform. Rocks of the terrigenous succession are intensely dislocated and fragmented, in part converted into tectonic melange. Their thickness probably reaches a hundred metres.

The third tectonic unit belongs to the middle of the lower nappes. It is made up mainly of a pelagic sedimentary succession thrusted onto the second unit. The pelagic succession is represented by the Tomasha Formation $\left(\mathrm{D}-\mathrm{C}_{1} t m\right)$ and Bidana Formation $(\mathrm{Cbd})$. The Tomasha Formation is composed of thinly layered green, grey and dark grey to black pelagic cherts interbedded with green shales. Its thickness does not exceed ten metres. The Bidana Formation (up to $100-150 \mathrm{~m}$ in thick) overlaps the Tomasha Formation and is composed of grey micritic limestones, alcarenites and calcirudites with intercala- tions of pelagic chert and shale. In some places in the Khaidarkan field (see Fig. 7), limestones of the Bidana Formation are overlain by conglomerates/debris-flow deposits up to $150-200 \mathrm{~m}$ thick $\left(\mathrm{C}_{2}\right)$ with clasts and olistoliths of bedded cherts of the Tomasha Formation.

The fourth tectonic unit is the upper part of the lower nappes and is developed on the northern flank of the Khaidarkan deposit field. It is made up of Silurian-Carboniferous carbonate platform rocks of the so-called Aktur sedimentary succession represented by shallow-water reef limestone. The unit is thrusted onto the deposits of the terrigenous and condensed successions.

The primary nappe structure of the areas studied is disturbed by post-nappe tectonic movements, especially in the Khaidarkan region, were nappes were deformed into folds and broken by subvertical faults.

In the central and northern part of the Khaidarkan deposit, the tectonic melange occupies a significant area (see Fig. 6). Melange is characterized by a block-in-matrix fabric. The matrix is represented by disrupted shales of the terrigenous and pelagic sedimentary successions characterized by lacking stratal continuity, scaly cleavages and locally with a black clay fraction. Blocks in the melange have an elongated lozenge-like form characteristic of melanges (see Festa et al., 2010). They are represented by relatively weakly tectonized rocks of the same sedimentary successions.

\section{DESCRIPTION OF THE OLISTOSTROME}

Kadamzhai field. Characteristic structures showing the relationship of the Early Moscovian olistostromes with the surrounding formations are developed on the eastern flank of the Kadamzhai field in the Karabiy and Aktash Mountains (Fig. 6). Here, in the core part and on the southern flank of the Kauzan Antiform, the parautochthonous tectonic unit is exposed and represented by the Alay limestones and Tolubai Formation. In the south of the mapped territory on the Sartala Plateau and the Shale Wedge (see Fig. 6), the second and third tectonic units (lower nappes) are developed. They are made up of Silurian to Devonian shales, turbidites, yellow dolomites and conglomerates (a terrigenous succession) and, locally, pelagic siliceous deposits (pelagic sedimentary succession). In many places, the Silurian to Devonian schists are transformed into clay melange, including blocks of older Early Paleozoic or Ediacaran(?) phtanites.

In the Aktash Mountains, the Alay limestones are tectonically dismembered and imbricated into thrust limestone sheets lying on each other and divided by brecciated zones. To the south, these sheets are exfoliated from the main limestone body exposed in the Aktash Mountains, and are wedged into flysch deposits of the Tolubai Formation developed in the Karabiy Mountains. These limestone sheets thin to the south and eventually wedge out and disappear among the flysch strata (Figs. 6 and 9).

Farther to the south and closer to the Sartala Plateau, limestone sheets are isolated from the main limestone body and form separate tectonic caps (tectonic klippen) and/or large olistoplaques lying on the flysch of the Tolubai Formation (Figs. 6 and 9). The sheets reach several hundred metres long and a few tens of metres thick. The limestones are brecciated at the bottom contact of these sheets. The underlying terrigenous rocks are also brecciated and sheared. Shear zones reach a thickness of several decimetres and up to metres (Fig. 10A, B). The upper contacts of these limestone units with the overlapping flysch are, as a rule, also tectonically fragmented. Locally 


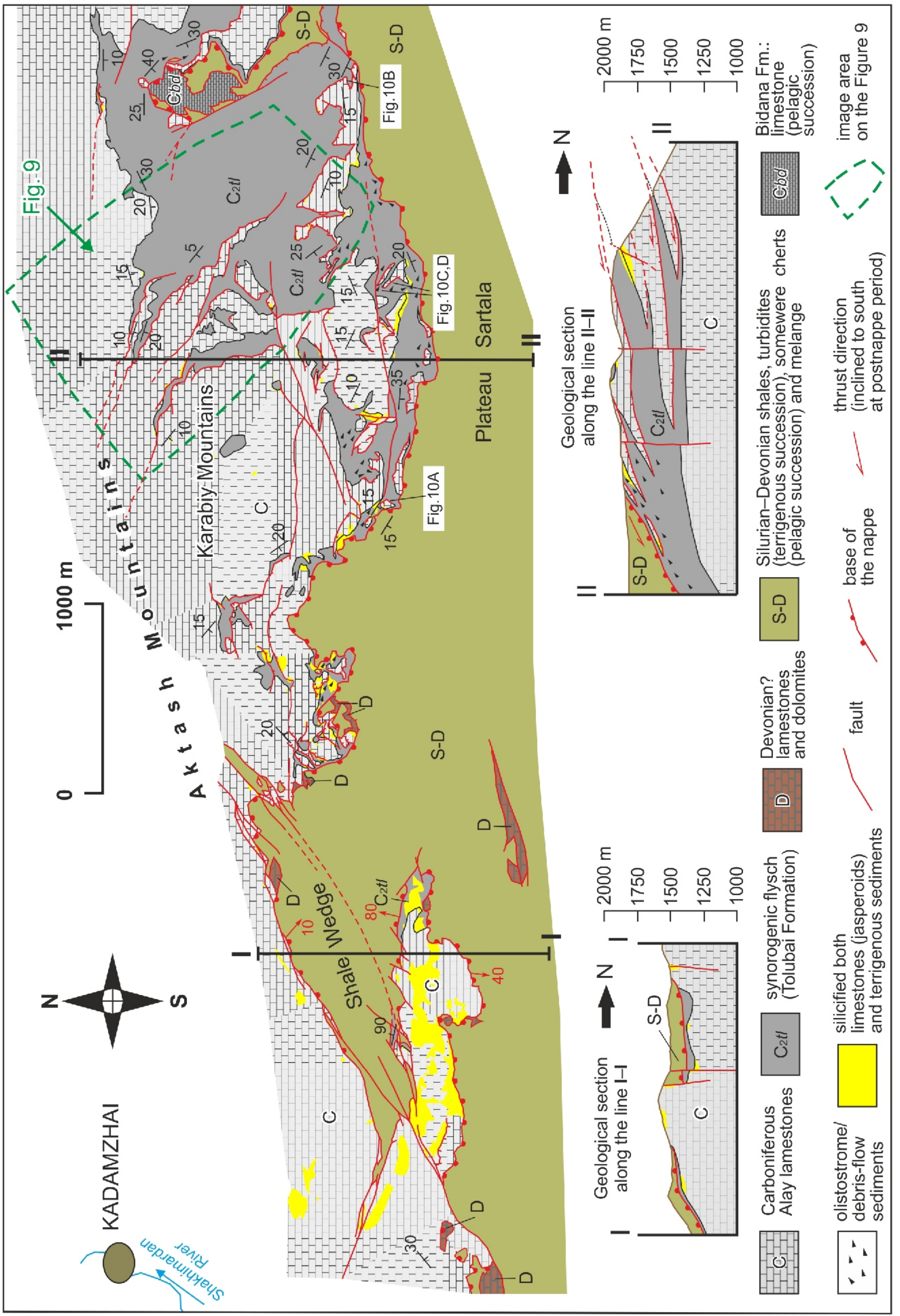

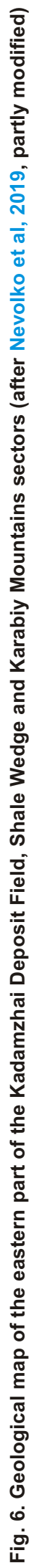




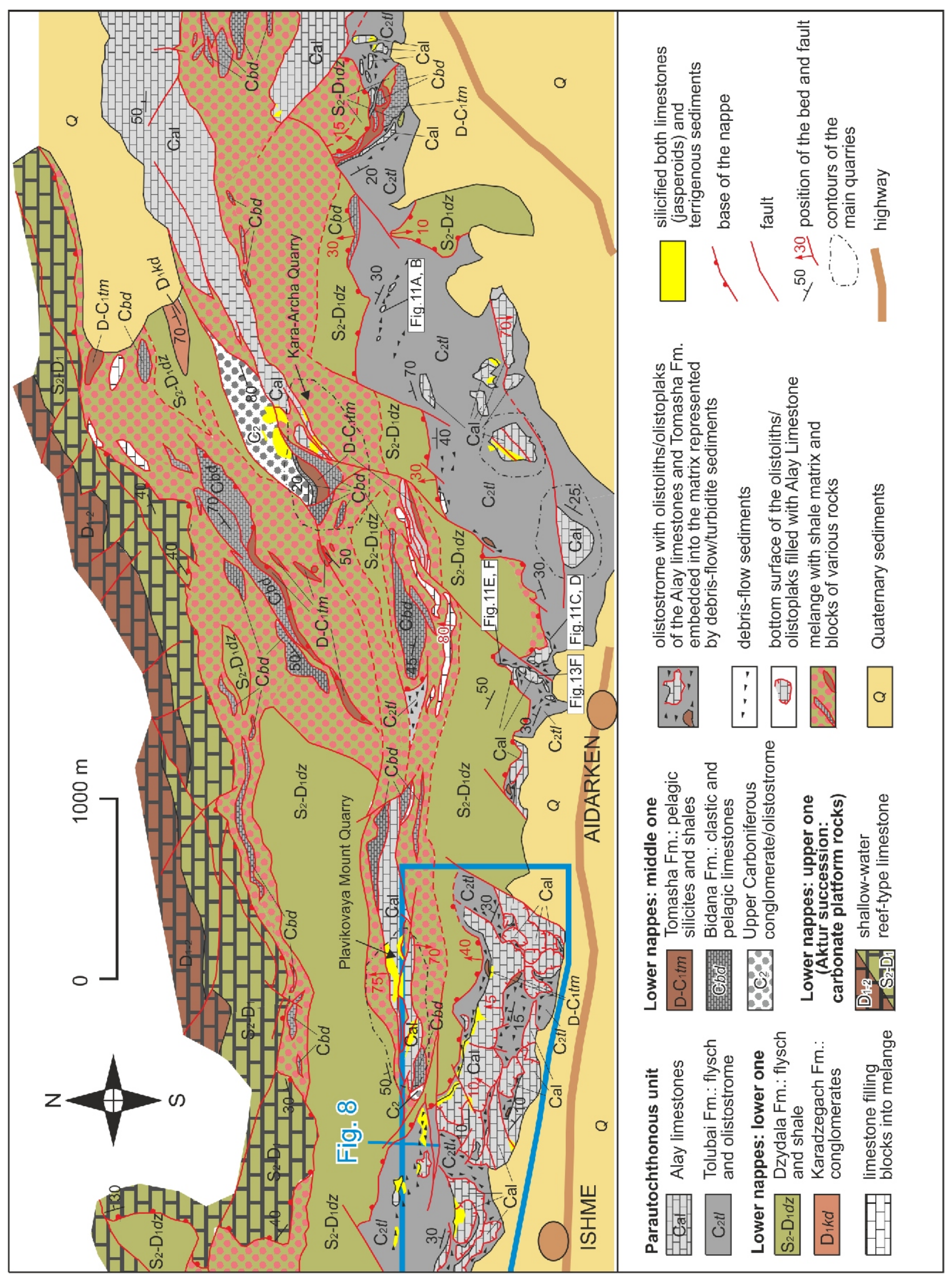

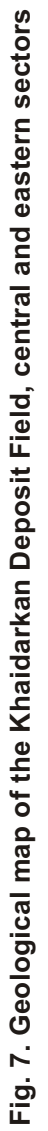




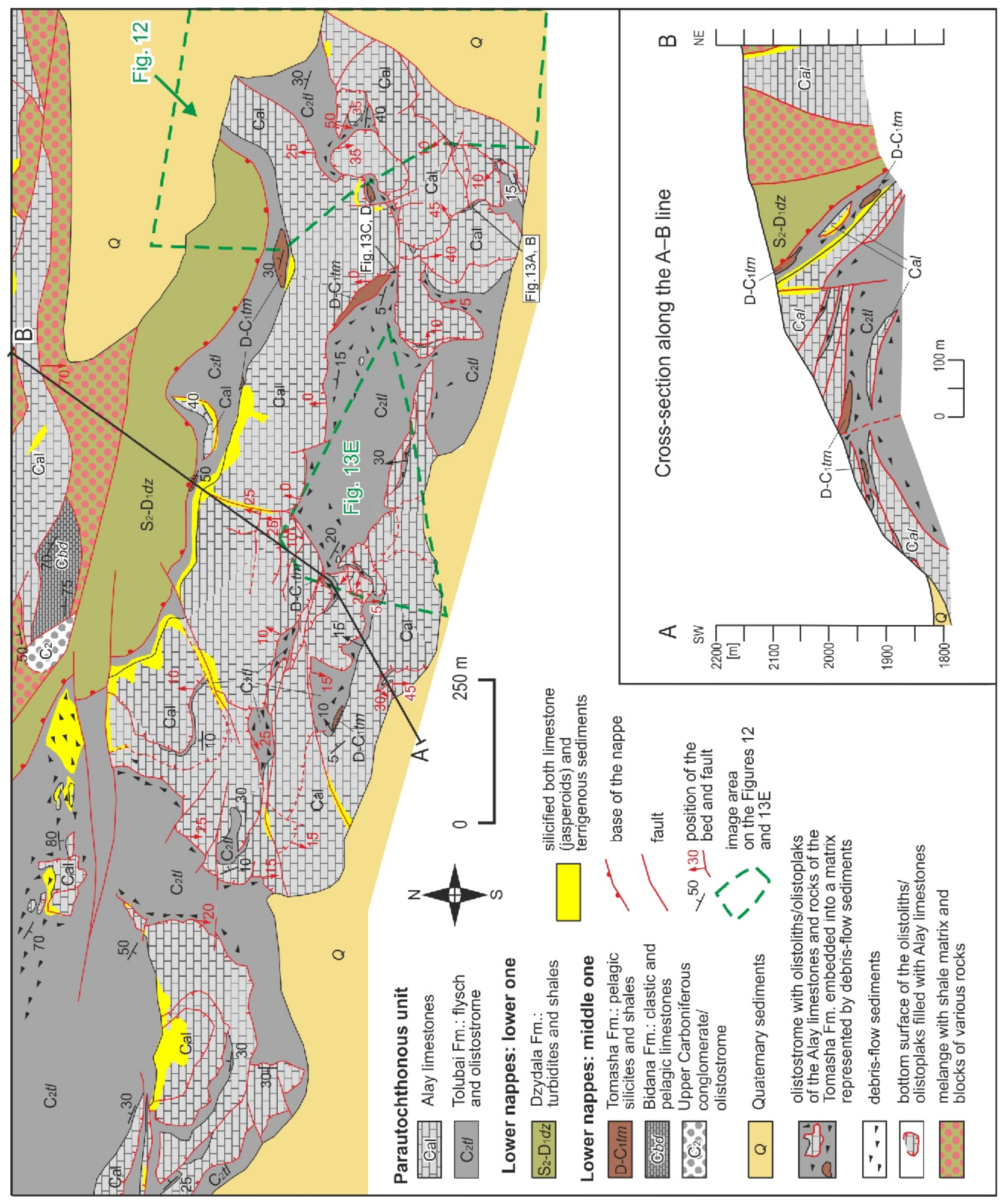

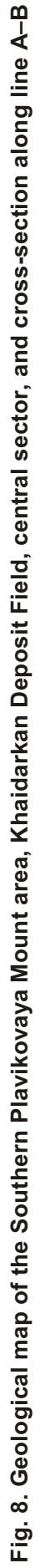




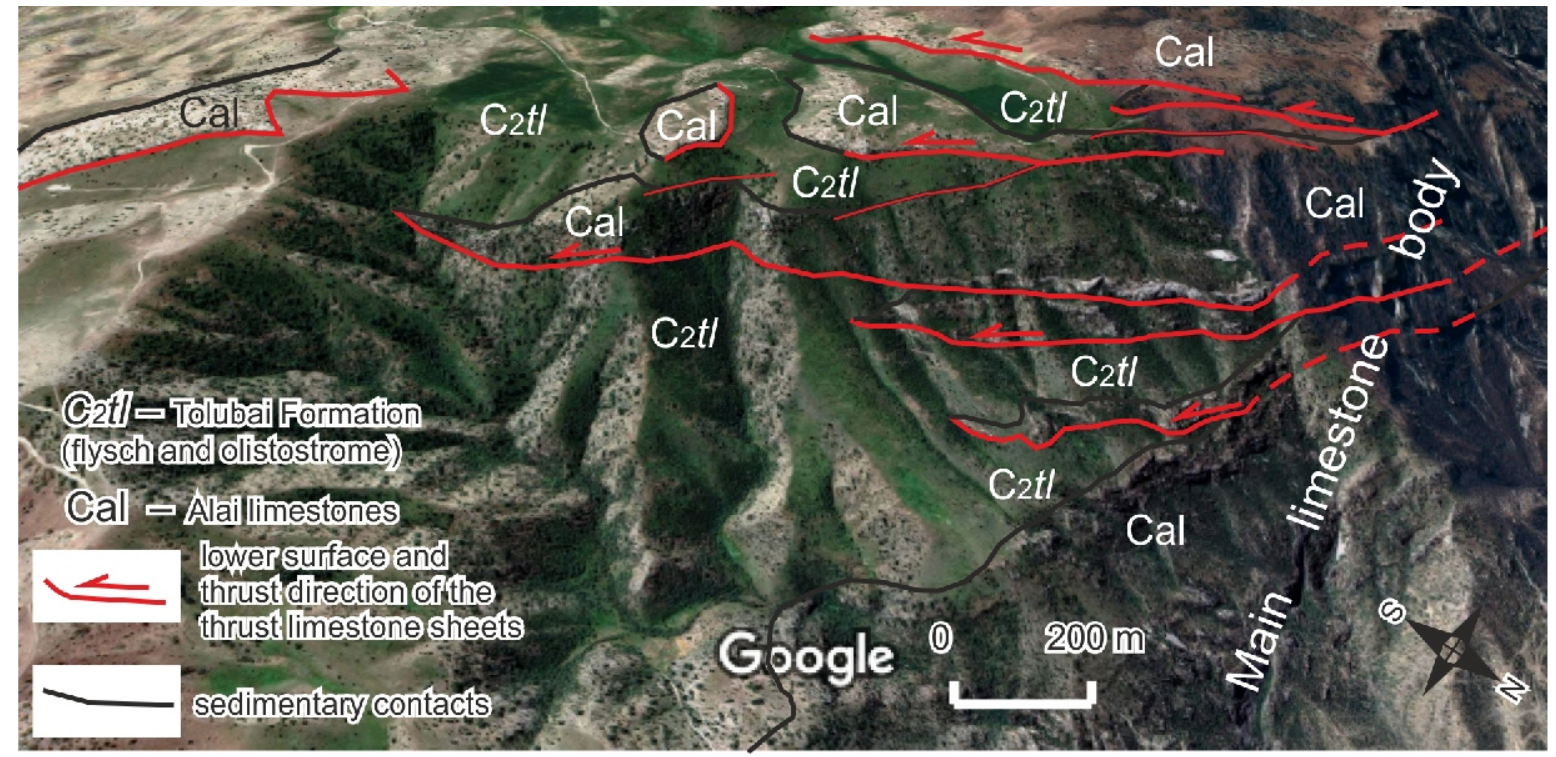

Fig. 9. Image from Google Maps: the Kadamzhai Deposit Field, Karabiy Mountains sector

Delamination of the Alay limestones into the thrust sheets exfoliated from the main limestone body and wedged into the flysch sediments of the Tolubai Formation; for location see Figure 6

flysch deposits overlie the limestone bodies, indicating synsedimentary movements of the limestone sheets into the flysch basin.

In the southern part of the Karabiy Mountains near the Sartala Plateau, some large (up to $>1 \mathrm{~km}$ long) limestone sheets are associated with an olistostrome represented by small (up to a few tens of metres across) olistoliths of the same limestone hosted in debris-flow deposits (Fig. 10C, D). The debris-flow deposits are mostly represented by unsorted ma- trix-supported conglomerates and breccias, in some places gravelly sandstones with predominantly limestone clasts. The association of the large limestone sheets with the typical olistostrome suggests that such sheets belong to olistoplaques.

In the eastern part of the studied area on the left side of the Karangly-Sai, the tectonic cap (remnant) of the third tectonic unit made of limestone of the Bidana Formation and locally cherts of the Tomasha Formation of the pelagic sedimentary succession was mapped (see Fig. 6). This remnant lies both on
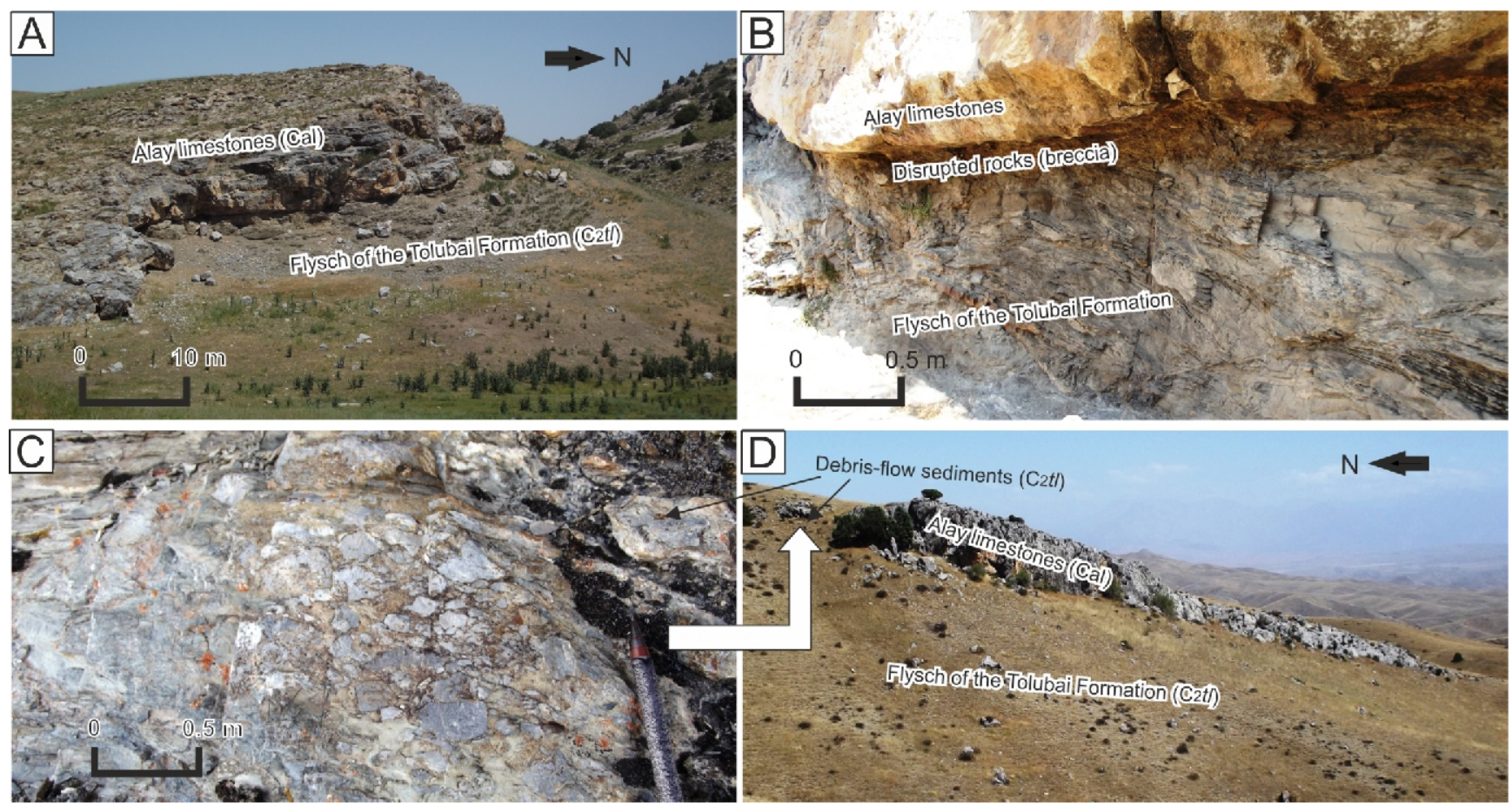

Fig. 10. Thrust sheets and/or olistoplaques of the Alay limestones (Kadamzhai Deposit Field)

A - thrust limestone sheet lying on flysch of the Tolubai Formation; B - lower contact of a limestone sheet; $\mathbf{C}$ - debris-flow deposits near limestone olistoplaque; D - limestone olistoplaque overlying flysch of the Tolubai Formation; for location see Figure 6 
the tectonic melange formed by the rocks of the terrigenous/pelagic sedimentary successions and on the parautochthonous unit filled with the Tolubai Formation represented by the flysch containing olistostrome lenses. Small (several metres across) olistoliths of the bedded green cherts of the Tomasha Formation were observed in the olistostrome lenses. The lower contact of these olistoliths is not exposed. The olistoliths are overlapped by sandstones of the Tolubai Formation. It appears, that the source for the olistoliths was the third tectonic unit made of the pelagic sedimentary succession.

Khaidarkan field. An Early Moscovian olistostrome was mapped in the southern part of the deposit field (Fig. 7). It forms a belt up to $10 \mathrm{~km}$ long and up to $1200 \mathrm{~m}$ wide in the area studied. The olistostrome belongs to the first (parautochthonous) tectonic unit. In the central and northern part of the field, the second and third tectonic units (lower nappes), destructured in places to form tectonic melange, are developed. They are tectonically overlain by the fouth tectonic unit comprising Silurian-Carboniferous carbonate platform rocks of the Aktur succession. In the central part of the field, including Mt. Plavikovaya and the Kara-Archa quarries, units of the Alay limestone emerge at the surface within the melange in steep antiformal structures bounded by the faults (see Fig. 7).

At the eastern edge of the Late Carboniferous olistostrome outcrop (see Fig. 7), a group of olistoliths and olistoplaques closely adjacent to each other are located. They are represented by:

- light grey massive, light and black-grey thickly and thinly layered micritic limestone of the Pyrkaf and Gaz formations;

- green and black shales of the Dzydala (?) Formation;

- grey and dark grey micrites and calcarenites of the Bidana Formation;

- green shales and layered cherts of the Tomasha Formation.

The limestones in these olistoliths are often fractured and locally transformed into tectonic breccias. Clayey shales filling the olistoliths are dislocated in small folds, sheared and in places transformed into melange. Plastic shale fills the spaces between the rigid limestone blocks, and obviously were injected between them.

The composition of olistoliths similar to that described is more or less maintained along the entire olistostrome belt on the southern flank of the Khaidarkan field. Olistolith size ranges from small slumps (up to $0.5-1 \mathrm{~m}$ across) to huge olistoplaques (up to $1 \mathrm{~km}$ long). Olistoliths are dispersed in a matrix or lie back to back on each other (see Figs. 6, 7 and 10-12). The olistostrome matrix is made of debris flow deposits forming sedimentary lenses within fine-medium and coarse-grained turbidites of the Tolubay Formation. Debris flow deposits are represented by mostly unsorted matrix-supported conglomerates and breccias. Clasts in these sediments are mostly represented by the same rocks that make up large olistoliths, such as limestone, bedded chert, clayey shale and sandstone. In some exposures, it can be seen that the limestone olistoliths lie on non-tectonized debris-flow deposits of the olistostrome matrix (Figs. 11 and 13).

In the southwestern part of the mapped area to the south of the Plavikovaya Mount Quarry, a group of the large olistoplaques made of limestones of the Pyrkaf Formation and locally of the Gaz Formation are developed (Figs. 7, 8 and 12 13). These belong to the parautochthonous unit crumpled into an anticline fold (see Fig. 8). Limestone sheets overlie debris-flow deposits with clasts of the same limestone and cherts of the Tomasha Formation (Fig. 13C-F). Debris-flow deposits overlie thin- or medium-bedded sandy-clay flysch of the
Tolubay Formation. In some places, debris-flow deposits lie between the large limestone sheets and laterally wedge out: in these cases, the limestone sheets lie on top of each other and are separated by limestone breccias (Fig. 13A, B). Introduction of plastic clay olistostrome matrix into cracks (up to 2-3 m thick, up to tens of metres long) in the limestones was observed. Slides (up to $100 \mathrm{~m}$ long) filled with intensely dislocated green and black shales and cherts of the Tomasha Formation were also identified among the terrigenous matrix of the Tolubay Formation between the limestone olistoplaques (Fig. 8).

Thus, in the Kadamzhai and Khaidarkan fields, the Early Moscovian olistostrome contains olistoliths and olistoplaques composed of:

- massive and bedded, often brecciated Alay limestones (mainly Pyrkaf and Gaz formations);

- bedded green-grey shales, cherts and limestones (Tomasha and Bidana formations of the pelagic succession);

- black and green shales (Dzydala Formation of the terrigenous succession).

Rock fragments of the first (parautochthonous), second and third (lower nappes) tectonic units are represented in this olistostrome. Some strata, especially the Tomasha Formation shales/cherts, are commonly tectonized up to melange grade only within olistoliths located in the non-tectonized olistostrome matrix.

Quartz metasomatism is manifested along the contact of the terrigenous rocks of the Tolubai Formation and Alay limestones in many places. Both limestones and terrigenous rocks are fully or partially silicified and enriched with iron oxides along the contact. Frequently quartz metasomatism forms "jasperoids": fully silicified rocks. Antimony-mercury and locally gold mineralization occurs mainly among the silicified rocks (see Vaulin, 2016; Nevolko et al., 2019 and references therein). Therefore, the identification of the olistostromic nature of the many limestone bodies, the clarification of their structure and accurate reflection of the boundaries of the olistoliths/olistoplaques of the Kadamzhai and Khaidarkan deposits is important and makes it possible to both exactly predict the position of the ore bodies and construct drilling plans.

\section{RECONSTRUCTION AND DISCUSSION}

The Early Moscovian olistostrome in the Kadamzhai and Khaidarkan fields contains fragments of both the parautochthon and lower nappes of the northern (Bukantau-Kokshaal after Biske, 1996, 2015) branch of the Southern Tian Shan nappe belt. Therefore the olistostrome was formed as result of denudation of the uplifted nappe belt, and can be described as a sub-nappe olistostrome in a collisional tectonic setting (sensu Festa et al., 2016). Such olistostromes have been described in many orogens (Leonov, 1981; Festa et al., 2016 and references therein). They have also been observed by the author in the Ukrainian Flysch Carpathians, where their identification is difficult because the olistoliths and matrix are composed of the same flysch (Hnylko, 2000) or molasse (Hnylko, 2014) deposits, unlike in the Southern Tien Shan area studied, where the blocks and matrix are different in lithology.

In most geodynamic models, the formation of the northern branch of the Southern Tian Shan nappe belt is associated with subduction of the Turkestan Ocean crust and subsequent collision of the Alay and Kyrgyz-Kazakh continents. The collision was accompanied by incorporating the northern passive margin of the Alay microcontinent into the subduction zone inclined to the north beneath the active Kyrghyz-Kazakh continental mar- 

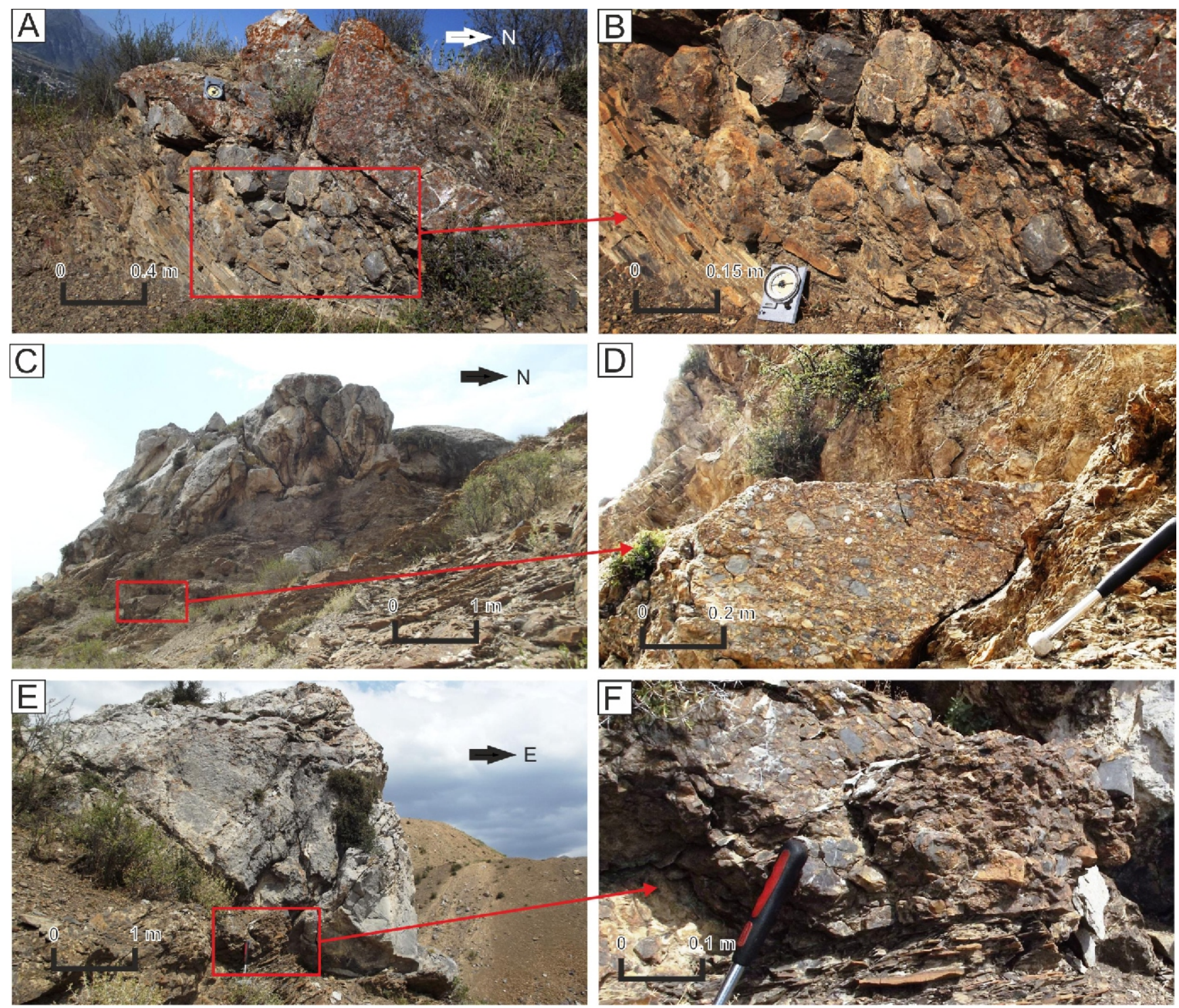

Fig. 11A-F - olistoliths of the Alay limestones among debris-flow/turbidite deposits of the Tolubai Formation (Khaidarkan Deposit Field)

For location see Figure 7

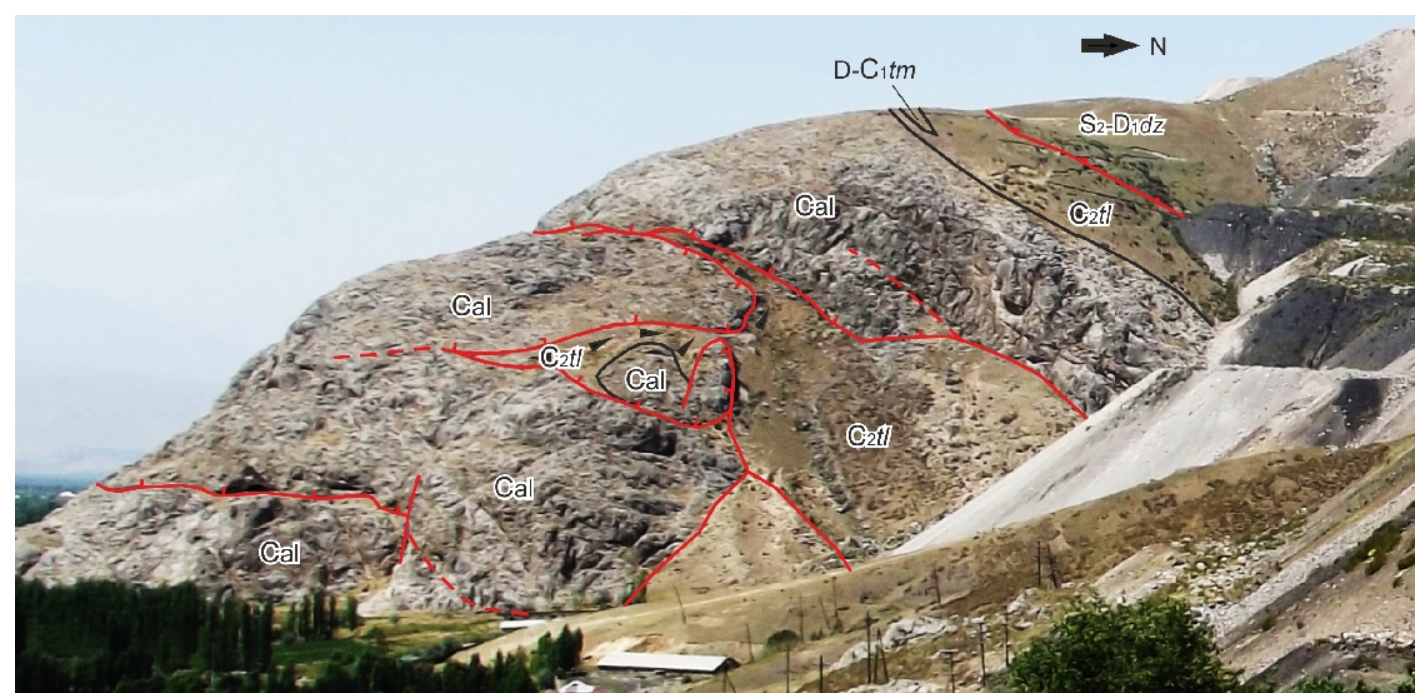

Fig. 12. Olistoliths and/or olistoplaques of the Alay limestones in the Southern Plavikovaya Mount area (Khaidarkan Deposit Field)

For location and explanations see Figure 8 

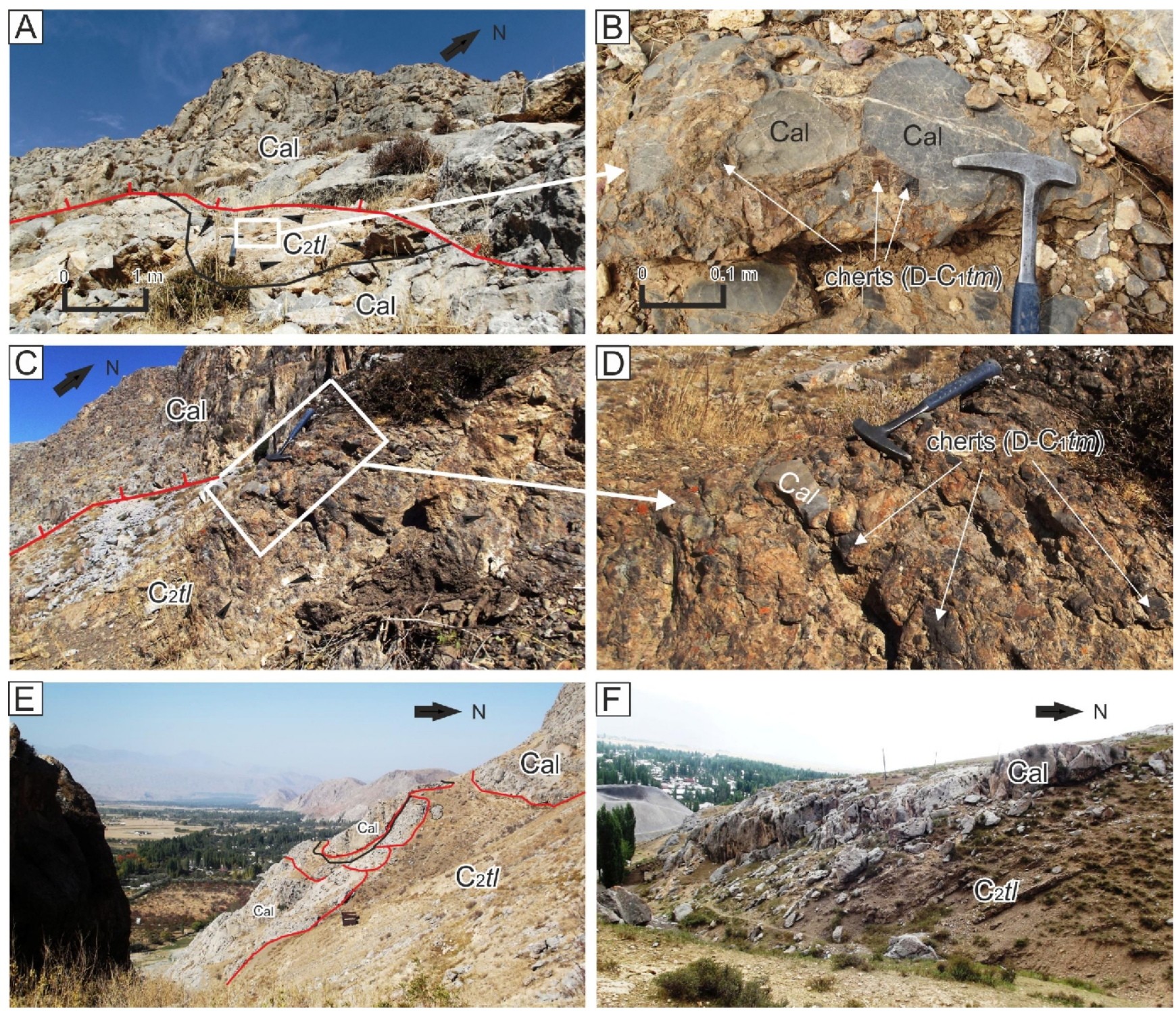

Fig. 13. Olistoliths and/or olistoplaques of the Alay limestones among the debris-flow/turbidite deposits of the Tolubai Formation (Khaidarkan Deposit Field)

A - amalgamated large limestone olistoplaques and thin lenses of debris-flow deposits between the olistoplaques; B - debris-flow sdeposits situated between limestone olistoplaques contain clasts of the Alay limestone and cherts of the Tomasha Formation; C, D - Alay limestone olistoplaque overlying debris flow/flysch deposits containing clasts of both limestone (Alay-type) and cherts (Tomasha Formation, pelagic succession); $\mathbf{E}, \mathbf{F}$ - olistoliths and/or olistoplaques of the Alay limestones overlying debris-flow/flysch deposits of the Tolubai Formation; for location and explanations see Figures 7 and 8

gin (Fig. 15; Biske, 1996, 2015, 2018; Burtman, 2006, 2015; Biske and Seltmann, 2010 and references therein).

The tectonic units exposed within the Kadamzhai and Khaidarkan deposits belonged to the northern passive margin palaeogeographic elements of the Alay microcontinent in mid-Paleozoic pre-collision time (see Figs. 4 and 15). The elements were represented by the shelf (the Alay sedimentary succession), the continental slope and possibly the open ocean (terrigenous and pelagic sedimentary successions) and carbonate platforms (the Aktur sedimentary succession in the area studied). To the north, the Turkestan Ocean marked by Paleozoic (pre-Carboniferous) ophiolites was present (Burtman, 1976, 2015). An accretionary prism containing oceanic crust remnants was formed and subduction volcanism took place periodically on the Kyrgyz-Kazakh active continental margin (Biske, 1996, 2015; Burtman, 2006, 2015 and references therein).
As a result of the collision and incorporation of the Alay microcontinent into the subduction zone, the palaeogeographic elements of the Alay microcontinent passive margin were detached from the basement, added to the accretionary prism of the Kyrgyz-Kazakh active margin and thrusted onto the Alay microcontinent. The accretionary-collisional prism was formed (now represented by the northern Bukantau-Kokshaal branch of the Southern Tian Shan nappe belt). The nappe movement to the south (onto the Alay microcontinent) is reflected by the nappe sequence (see Porshnyakov, 1973; Biske, 1996; Biske and Seltmann, 2010), by rejuvenation of synorogenic flysch from the upper nappes to the lower nappes (Biske, 1996, 2015) and by structural analysis data (Burtman and Schmidt, 1970; Bolgar and Rezvoy, 1971; Burtman, 1976, 2006).

The foredeep basin was formed on the subsiding carbonate shelf ahead the advancing front of the accretionary-collisional prism. Turbidity and debris-flow sediments (Tolubai Formation) 


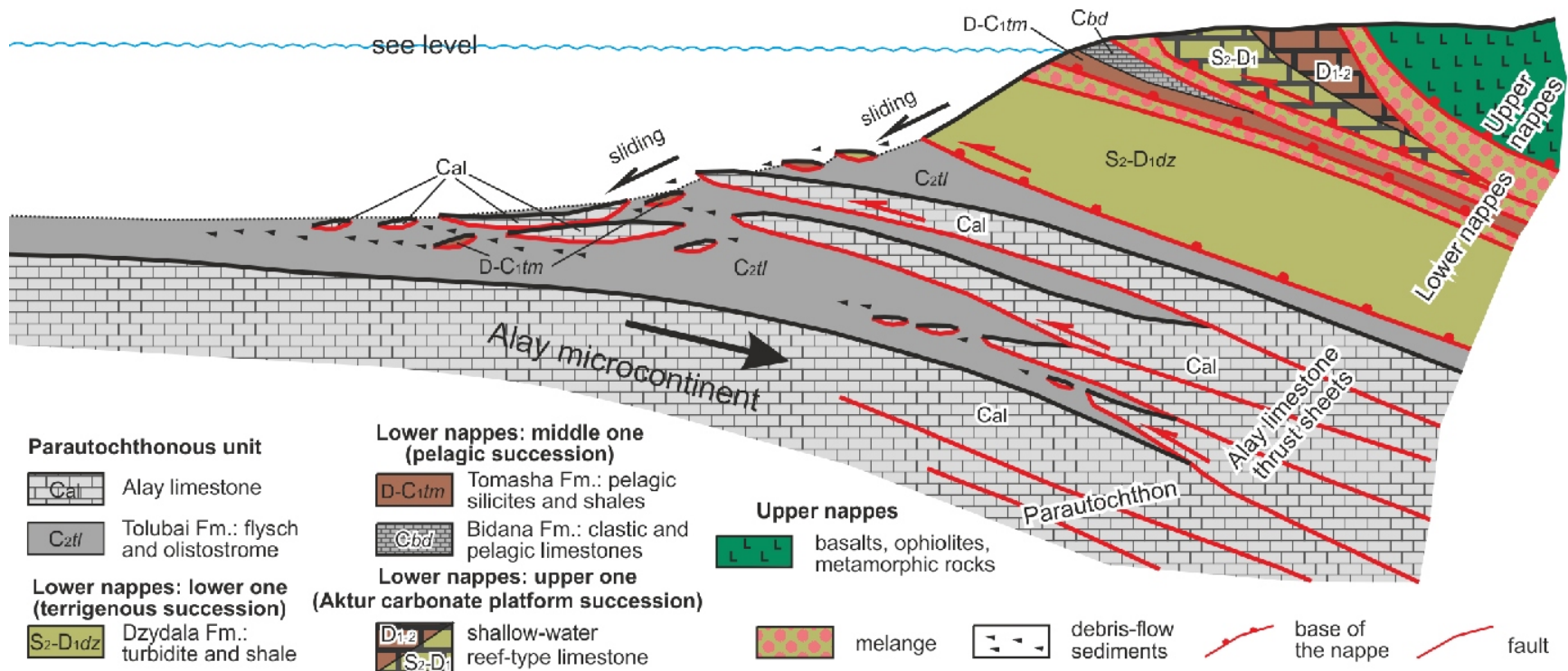

Fig. 14. Schematic formation of the olistostrome now developed in the Kadamzhai and Khaidarkan fields among the flysch deposits of the Tolubai Formation; Early Moscovian

No scale; in part using the reconstructions of Biske $(1996,2015,2018)$ and Burtman $(2006,2015)$

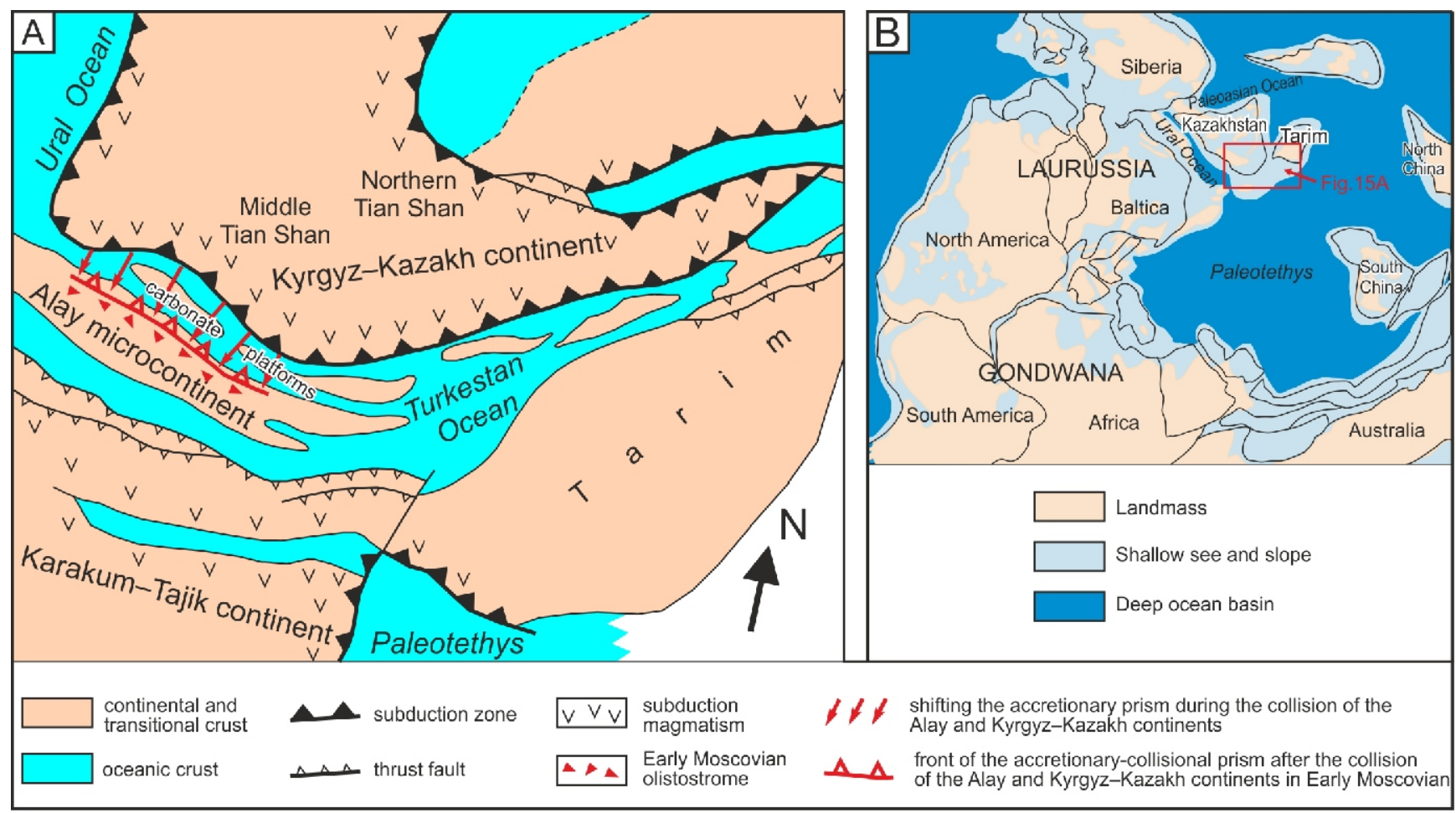

Fig. 15A - paleogeographic/tectonic reconstruction of the Tian Shan region for the Middle Carboniferous (approximately $315 \mathrm{Ma}$ ) before the collision of the Alay and Kyrgyz-Kazakh continents pictured by black lines, no scale, after Biske (2018) slightly simplified and modified; the position of the accretionary-collisional prism after this collision as well as the olistostrome location in the Early Moscovian (approximately $310 \mathrm{Ma}$ ) is pictured by red lines; B - contours of the main continents and oceans in the Early Carboniferous (338-323 Ma) after Golonka et al. (2006, simplified) and location of Figure 15A 
accumulated in this basin due to denudation of the nappe pile of the prism (Figs. 14 and 15).

As a result of continental subduction, the Alay microcontinent carbonate shelf (parautochthonous tectonic unit) was partly tectonically dismembered and imbricated into thrust limestone sheets attached to the accretionary prism from below. These structurally lowest sheets were thrusted onto the foredeep basin sediments. Frontal parts of the thrust sheets were disintegrated, broke away and gravitationally slid into unconsolidated sediments of the foredeep basin, forming large limestone olistoliths and olistoplaques. This process is captured on the eastern flank of the Kadamzhai field in the Karabiy and Aktash mountains, where the Alay limestones are tectonically imbricated into thrust limestone sheets, exfoliated from the parautochthon and wedged into the flysch deposits of the Tolubai Formation (see Figs. 6 and 9). The tectonic sheets are laterally replaced by an olistostrome formation to the south (see Fig. 10C, D) suggesting synsedimentary protrusion of limestone wedges into the flysch foredeep basin. In addition, such lateral structure indicates gravitational displacement of the slides/debris-flows to the south, which is the same as the movement direction of the tectonic nappes.

Thus, tectonically imbricated Alay limestone sheets exfoliated from the parautochthon were synsedimentarily thrusted to the south onto the sediments of the flysch foredeep basin as well as being the source for the limestone olistoplaques and olistoliths. Olistoliths comprising fragments of the terrigenous and pelagic sedimentary successions were slid from the lower nappes. Submarine sliding was accompanied by debris flows and turbidity currents (see Fig. 14).

Limestone, and especially siliceous-clay strata, incorporated into the nappe pile (accretionary prism), underwent tectonic deformation up to transformation into melange. Blocks of these dislocated/melange rocks were slid from the uplifted prism into the foredeep olistostrome basin. The results of this process are well documented at the Haidarkan deposit, where in some outcrops, the Tomasha Formation shales/cherts are tectonized up to melange only within olistoliths located in a non-tectonized olistostrome matrix. Tectonic/metamorphic processes within the accretionary prism were developed on the continuation of the mapped structure (the Isfairam River valley, $10 \mathrm{~km}$ south of the Chauwai fields, see Fig. 3) in the accretionary melange where greenstone and even glaucophan schists are present as blocks in the melange matrix (Biske, 1983, 1996).

In the final collisional stage, the olistostrome was emplaced beneath the accretionary-collisional prism, and was covered by the lower nappes made of terrigenous and pelagic sedimentary successions.

\section{CONCLUSIONS}

A Late Carboniferous (Early Moscovian) olistostrome is developed on the Kadamzhai and Khaidarkan fields and contains the olistoliths/olistoplaques composed of: (1) massive and bedded shallow-water Alay limestones represented by the Peshkaut ( $\left.\mathrm{C}_{1} p s\right)$, Gaz ( $\left.\mathrm{C}_{1-2} g \mathrm{z}\right)$ and Pyrkaf $\left(\mathrm{C}_{2} p r\right)$ formations; (2) fragments of the pelagic sedimentary succession made by bedded green-grey shales and cherts of the Tomasha Formation $\left(\mathrm{D}-\mathrm{C}_{1} t m\right)$ and limestones of the Bidana Formation (Cbd); (3) fragments of the terrigenous sedimentary succession with turbidites and black and green shales of the Dzydala Formation $\left(\mathrm{S}_{2}-\mathrm{D}_{1} d z\right)$. The olistostrome matrix comprises debris-flow deposits which often underlay the olistoliths and form sedimentary lenses within the fine-medium and coarse-grained turbidites of the Tolubay Formation $\left(\mathrm{C}_{2} t\right)$.

The olistostrome accumulated in a foredeep basin ahead the advancing front of the accretionary-collisional prism formed as a result of the Turkestan Ocean lithosphere subduction and subsequent collision of the Alay microcontinent and Kyrgyz-Kazakh continent as well as incorporating the passive margin of the Alay microcontinent into the subduction zone. In mid-Paleozoic pre-collision time, the Alay microcontinent passive margin included shelf (the Alay limestones), continental slope, and possibly open ocean (terrigenous and pelagic sedimentary successions). These paleogeographic elements of the passive margin were detached from the base and added to the accretionary prism as a result of incorporating the Alay microcontinent. The new accretionary-collisional prism (=northern Bukantau-Kokshaal branch of the Southern Tian Shan nappe belt in the Alay segment) began to include both the upper nappes (remnants of the Turkestan ocean) and the lower nappes (passive margin terrigenous and pelagic sedimentary successions as well as carbonate platforms) covering the parautochthon (Alay limestones).

The parautochthon was partly tectonically dismembered into thrust limestone sheets attached to the prism. Frontal parts of these thrust sheets disintegrated and were gravitationally slid into the foredeep basin forming the large olistoliths and olistoplaques. Olistoliths made of fragments of the terrigenous and pelagic sedimentary successions were slid from the lower nappes. Submarine sliding was accompanied by debris flows and turbidity currents.

Tectonic breccia up to melange is present in some olistoliths (especially those made of shales and cherts) located in the non-tectonized olistostrome matrix. This observation suggests tectonic processes active within the accretionary prism and subsequent sliding of the tectonized blocks into the olistostrome basin.

The Late Carboniferous olistostrome can be regarded as a sub-nappe olistostrome in a collisional tectonic setting (sensu Festa et al., 2016).

Ore-bearing silicified rocks ("jasperoids") with antimony-mercury and gold mineralization are located predominantly along the contacts of the Tolubai Formation terrigenous rocks and the Alay limestones including the olistolith/olistoplaque boundaries.

Acknowledgments. We thank Real Gold Resources Corporation and the Adyshev Institute of Geology of the National Academy of Science of the Kyrgyz Republic for support of the geological research and access to mineral deposits in Kyrgyzstan. We are very grateful to Prof. Yu.S. Biske, Prof. V.S. Burtman and Dr. M. Krobicki for constructive comments and useful remarks. 


\section{REFERENCES}

Alexeiev, D.V., Kröner, A., Hegner, E., Rojas-Agramonte, Y., Biske, Y.S., Wong, J., Geng, H.Y., Ivleva, E.A., Mühlberg, M., Mikolaichuk, A.V., Liu, D., 2016. Middle to Late Ordovician arc system in the Kyrgyz Middle Tianshan: from arc-continent collision to subsequent evolution of a Palaeozoic continental margin. Gondwana Research, 39: 261-291.

Aristov, V.A., Chernyshuk, V.P., 1984. New data on stratigraphy of siliceous sediments of the Southern Tien Shan (in Russian). Doklady Akademii Nauk SSSR, 274: 417-421.

Belousov, V.I., 1998. On the role of olistostromes and nappes in the geology of the Turkestan-Alay (in Russian). Geologiya razvedka, 6: 33-45.

Belousov, V.I., Beer, M.A., 1989. Flysch-olistostrome formation of the Alay (in Russian). Izvestiya vysshikh uchebnykh zavedeniy. Geologiya i razvedka, 6: 3-12.

Belov, S.I., Aksenov V.A., Aksenenko V.V., 1991.State geological map of the USSR. Scale 1:50,000. South Fergana mercury-antimony belt. Turkestan-Alay group of the sheets (in Russian). Archives of the South Kyrgyz Geological Expedition, Osh, Kyrgyztan.

Biske, Yu.S., 1983. Shaly mélange of Maidan and overthrusts of the Southern Ferghana (in Russian). Vestnik of Leningrad University, Series 6: 40-45.

Biske, Yu.S., 1996. Paleozoic Structure and History of Southern Tian-Shan (in Russian). Leningrad State University, Leningrad.

Biske, Yu.S., 2015. Geology and evolution of the Central Asian orogenic belt in Kazakhstan and the western Tianshan. In: The Central Asian Orogenic Belt. Geology, Evolution, Tectonics and Models (ed. A. Kroner): 6-49. Borntraeger Science Publishers, Stuttgart.

Biske, Yu.S., 2018. The Southern Tian-Shan: upgrading the geologic synthesis (in Russian). Vestnik of Saint-Petersburg University. Earth Sciences, 63: 416-452.

Biske, Yu.S., Seltmann, R., 2010. Paleozoic Tian-Shan as a transitional region between the Rheic and Urals-Turkestan oceans. Gondwana Research, 17: 602-613.

Bolgar, B.D., Rezvoy, P.D., 1971. Materials on the morphology of thrust structures in the Alay Range (in Russian). Geologicheskiy sbornik Lvovskogo universiteta, 13: 179-182.

Burtman, V.S., 1976. Structural Evolution of Paleozoic Fold Systems (Variscides of Tian-Shan and Caledonides of Northern Europe) (In Russian). Nauka, Moscow.

Burtman, V.S., 2006. Tien Shan and high Asia. Tectonics and Geodynamics in the Paleozoic (in Russian). GEOS, Moscow.

Burtman, V.S., 2015. Tectonics and geodynamics of the Tian Shan in the middle and late Paleozoic. Geotectonics, 49: 302-319.

Burtman, V.S., Schmidt, O.A., 1970. Investigation of the folded structure of the Teghermach Nappe remnant (in Russian). Proceedings of the USSR Academy of Sciences, 190: 1165-1168.

Cieszkowski, M., Golonka, J., Krobicki, M., Ślączka, A., Oszczypko, N., Waśkowska, A., Wendorff, M., 2009. The Northern Carpathians plate tectonic evolutionary stages and origin of olistoliths and olistostromes. Geodynamica Acta, 22 101-126.

Cherenkov, I.N., 1964. Landfalls and landslides in the flysch deposits of the Karavshin river basin (northern slope of the Turkestan Range) (in Russian). Litologiya i poleznyye iskopayemyye, 6 : 112-115.

Cherenkov, I.N., 1973. Upper Paleozoic flysch formation of the Gissar-Alay (in Russian). Donish, Dushanbe.

Chernyshuk, V.P., 1986. Olistostromes of the Turkestan-Alay (in Russian). Izvestiya Akademii Nauk SSSR, seriya geologicheskaya, 1: 57-63.

Dobretsov, N.L., Berzin, N.A., Buslov, M.M., 1995. Opening and tectonic evolution of the Paleo-Asian Ocean. International Geology Review, 37: 335-360.

Djenchuraeva, A.V., 1979. Stratigraphy and foraminifera of Middle Carboniferous deposited northern slopes of Turkestan-Alay (in Russian). llim, Frunze.
Festa, A., Pini, G.A., Dilek, Y., Cadegone, G., 2010. Mélanges and mélange-forming processes: a historical overview and new concepts. International Geology Review, 52: 1040-1105.

Festa, A., Ogata, K., Pini, G.A., Dilek, Y., Alonso, J.L., 2016. Origin and significance of olistostromes in the evolution of orogenic belts: a global synthesis. Gondwana Reseach, 39: 180-203.

Flores, G., 1955. Les résultats des études pour les recherches pétroliféres en Sicile: discussion. Proceedings of the 4th World Petroleum Congress, Section 1/A/2. Casa Editrice Carlo Colombo, Rome: 121-122.

Flores, G., 1959. Evidence of slump phenomena (Olistostromes) in areas of hydrocarbon exploration in Sicily. Proceedings 5th World Petroleum Congress, Section 1, pap. 13, Roma: 259-275.

Ghes, M.D., 2008. Terrain structure and geodynamic evolution of Caledonian Tian-Shan (in Russian). National Academy of Science of Kyrgyzstan, Bishkek.

Golonka, J., Krobicki, M., Pająk, J., Nguyen Van Giang, Zuchiewicz, W., 2006. Global Plate Tectonics and Paleogeography of Southeast Asia. Faculty of Geology, Geophysics and Environmental Protection, AGH University of Science and Technology, Kraków, Poland.

Golonka, J., Krobicki, M., Waśkowska, A., Cieszkowski, M., Ślączka, A., 2015. Olistostromes of the Pieniny Klippen Belt, Northern Carpathians. Geological Magazine, 152: 269-286.

Hsü, K.J., 1974. Mélanges and their distinction from olistostromes. Special Publication. Society of economic Paleontologists and Mineralogists, Tulsa: 321-333.

Hnylko, O.M., 2000. Chaotic formation of south-western part of the Krosno Zone - the products of origin and development of Dukla Nappe (Ukrainian Carpathians) (in Ukrainian). Geodynamics, 3 : 65-74.

Hnylko, O., 2014. Olistostromes in the Miocene salt-bearing folded deposits at the front of the Ukrainian Carpathian orogen. Geological Quarterly, 58 (3): 381-392.

Konopelko, D., Wilde, S.A., Seltmann, R., Romer, R.L., Biske, Yu.S., 2018. Early Permian intrusions of the Alai range: understanding tectonic settings of Hercynian post-collisional magmatism in the South Tien Shan, Kyrgyzstan. Lithos, 302-303: 405-420.

Kukhtikov, M.M., Vinnichenko, G.P., Cherenkov, I.P., 1983. Olistostromes of the folded regions of the Pamir and Gissar-Alay (in Russian). In: Tektonika Tyan'-Shanya i Pamira (eds. I.E. Gubin and S.A. Zakharov): 78-86. Science, Moscow.

Kurenkov, S.A., 1978. Serpentinite melange and olistostrome complexes of the Alay Range (South Tien Shan) (in Russian). Geotektonika, 5: 84-93.

Leonov, M.G., 1981. Olistostromes in the structure of the folded regions (in Russian). Nauka, Moscow.

Lucente, C.C., Pini G.A., 2008. Basin-wide mass-wasting complexes as markers of the Oligo-Miocene foredeep-accretionary wedge evolution in the Northern Apennines, Italy. Basin Research, 20: 49-71.

Mikhailov, A.Y., 1947. On the origin of limestone blocks (cliffs) in the Lower Carboniferous sediments of the eastern part of the Alay Range (in Russian). Byulleten' Mokovskogo obshchestva ispytateley prirody, 22: 33-48.

Nenakhov, V.M., Belov, S.I., 2000. Features of the formation of some dislocation structural-material complexes and folded structures of the northern slope of the Alay Range (in Russian). Vestnik Voronezhskogo universiteta, Geologiya, 5: 15-20.

Nenakhov, V.M., Lytochkin, V.Yu., Perfilyev, A.S., Kuznetsov, L.V., Stavsky, A.P., Morozov, O.L., Safonov, V.G., Berezner, O.S., Semenov, G.G., Mukhaylenko, V.G., 1992. Geological mapping of chaotic complexes (in Russian). Roskomnedra, Geokart, Moscow.

Nevolko, P.A., Hnylko, O.M., Mokrushnikov, V.P., Gibsher, A.S., Redin, Yu.O., Zhimulev, F.I., Drovzhak, A.E., Svetlitskaya, T.V., Fomynikh, P.A., Karavashkin, M.I., 2019. Geology and 
geochemistry of the Kadamzhai and Chauvai gold-antimony-mercury deposits: implications for new province of Carlin-type gold deposits at the Southern Tien Shan (Kyrgyzstan). Ore Geology Reviews, 105: 551-571.

Osmonbetov, K.O., Knauf, V.I., Korolev, V.T., eds., 1982. Stratified and intrusive formations of Kyrgyzstan. Volume 1 and 2 (in Russian). Ilim, Frunze.

Porshnyakov, G.S., 1968. On the tectonic position of limestone with a "mixed" fauna in the Middle Carboniferous of the Alay (in Russian). In: Voprosy regionalnoy geologii (ed. V.N. Ognev): 44-52. Leningrad State University Publishing House, Leningrad.

Porshnyakov, G.S., 1973. The Hercynides of Alay and Adjacent Southern Tien-Shan (in Russian). Leningrad University, Leningrad.

Richter, D., 1973. Olisthostrom, Olistholit, Olisthorymma und Olisthoplaka als Merkmale von Gleistungsund Resedimentationsvorgangen infolge synsedimentarer tectogenetischer Bewengungen in Geosynklinalbereichen. Neues Jahrbuch für Geologie und Palaeontologie Abhandlungen, 143: 304-344.

Sabirov, A.A., ed., 2012. Stratigraphic Dictionary of the Phanerozoic of Tajikistan (Northern, Central and South-Western Tajikistan) (in Russian). Nedra, Dushanbe.

Safonova, I., Kotlyarov, A., Krivonogov, S., Xiao, W., 2017. Intra-Oceanic arcs of the Paleo-Asian Ocean. Gondvana Research, 50: 167-194.

Vaulin, O.V., 2016. Structurally-material complexes of TurkestanAlay. Geodynamics. Geochemistry. Metallogeny. Ore content (in Russian). Rokizol. Bishkek.

Vishnevsky, L.I., Savochkina, E.N., Soloveva, M.N., 1978. Wild Flysch of the northern slope of the Alay Range (South Fergana) (in Russian). Byulleten' Moskovskogo obshchestva ispytateley prirody, Otdeleniye geologicheskoye, 1: 146-147.
Vishnevsky, L.I., Alekseev, A.S., Soloveva, M.N., 1982. Upper Paleozoic olistostrome strata of the northern slope of the Alay Range (South Fergana) (in Russian). Doklady Akademii Nauk SSSR (Reports of the USSR Academy of Sciences), 266: 936-940.

Wendorff, M., 2005. Lithostratigaphy of Neoproterozoic syn-rift sedimentary megabreccia from Mwambashi, Copperbelt of Zambia, and correlation with olistostrome succession from Mufulira. South African Journal of Geology, 108: 505-524.

Windley, B.F., Alexeiev, D., Xiao, W., Kroner, A., Badarch, G., 2007. Tectonic models for accretion of the Central Asian Orogenic Belt. Journal of the Geological Society of London, 164: 31-47.

Zhdan, A.V., 1985. About tectonic confinement of some ore manifestations of the Alay Range (in Russian). Geotektonika, 2: 57-66.

Zonenshain, L.P., Kuzmin, M.I., Natapov, L.M., 1990. Geology of the USSR: a plate-tectonic synthesis. Geodynamic Series 21. American Geophysical Union, Washington.

Zubtsov, S.E., 1997. New interpretation of collisional deformations in the Hercynides of the Alay Range (in Russian). Vestnik Sankt-Peterburgskogo universiteta, Seriya 7 , 4: 25-40.

Zubtsov, S.E., Porshnyakov, G.S., 1995. The structure and history of the formation of the Kauzan anticlinaloid (Southern Tien Shan) (in Russian). In: Voprosy stratigrafii i regional'noy geologii (eds. V.A. Prozorovsky and V.M. Tzeisler): 166-190. Publishing House of St. Petersburg University, St. Petersburg.

Zubtsov, Y.I., Porshniakov, G.S., Yagovkin, A.V., 1974. New sketch of pre-Mesozoic tectonics of Tian-Shan (in Russian). Doklady Akademii Nauk SSSR, 217: 1153-1156. 